\title{
Autonomous Energy Regions as a Proposed Choice of Selecting Selected EU Regions-Aspects of Their Creation and Management
}

\author{
Piotr Maśloch ${ }^{1}$, Grzegorz Maśloch ${ }^{2}$ (D) , tukasz Kuźmiński ${ }^{3}$, Henryk Wojtaszek ${ }^{1, *(\mathbb{D}}$ \\ and Ireneusz Miciuła 4 (D) \\ 1 Management Institute Management and Command Department, War Studies University, \\ 00-910 Warsaw, Poland; p.masloch@akademia.mil.pl \\ 2 Department of Local Government Economy and Financing, SGH Warsaw School of Economics, \\ 02-554 Warsaw, Poland; grzegorz.masloch@sgh.waw.pl \\ 3 Department of Process Management, Management Department, Wroclaw University of Economics, \\ 53-345 Wroclaw, Poland; lukasz.kuzminski@ue.wroc.pl \\ 4 Department of Sustainable Finance and Capital Markets, Faculty of Economics, Finance and Management, \\ University of Szczecin, 70-453 Szczecin, Poland; ireneusz.miciula@usz.edu.pl \\ * Correspondence: h.wojtaszek@akademia.mil.pl
}

Received: 21 October 2020; Accepted: 30 November 2020; Published: 6 December 2020

\begin{abstract}
There is a high demand for energy production, which is dependent on energy consumption and input. This demand affects socioeconomic development and quality of life. However, the lack of an innovative formal, legal, and organizational structure regarding public space in the European Union (EU) is problematic; one solution could be preparing and implementing grid services as part of distributed energy solutions (based on local and regional renewable resources), and involving local public, private, and profitable entities. Autonomous energy regions (AREs) are a response to this type of problem, as they can contribute to the creation of organizational and legal tools that counteract the marginalization of crisis areas, where undesirable socioeconomic phenomena intensify (and the conditions and management of the natural environments deteriorate). Investments in energy infrastructure based on distributed energy (mainly renewable energy sources) will be a tool for socioeconomic changes in affected areas. In terms of practical considerations in the energy field (i.e., keywords, barriers to energy consumption, and access to it), it is important to formulate recommendations regarding the creation, management, identification, and designation of autonomous energy regions (AREs) in the EU. In this case, postal questionnaires and a taxonomic method (Hellwig's method) were used. It is worth emphasizing that the creation of AREs is a modern requirement in connection with global $\mathrm{CO}_{2}$ emissions. Sustainable low-emission economies, according to the conducted research, may be introduced to the entire European Union. The lack of proposals for direction of regional development, in terms of autonomous energy regions, was indicated in this paper. There is a need to formulate specific recommendations regarding the possibility of creating and managing autonomous energy regions (AREs) in the European Union. Fortunately, there are natural, organizational, and social opportunities to begin this process. For example, local authorities may become leaders in creating a network of connections in emerging AREs, and communities might willingly make the effort to co-create AREs.
\end{abstract}

Keywords: autonomous energy regions; sustainable development; EU; governance 


\section{Introduction}

The demand for energy, production, consumption, and the share of energy expenditure in budgets of public entities, businesses, or households, have a significant impact on socioeconomic development and quality of life [1-4].

We believe that the solutions to problems provide no direction concerning regional development (specifically, autonomous energy regions).

The authors highlight the need to provide specific recommendations in regards to creating and effectively managing autonomous energy regions (AREs) in the European Union. It should be assumed that there are natural, organizational, and social possibilities to begin this process.

Local government authorities are, likely, able to become leaders in creating a network of connections in emerging AREs, and communities might willing make an effort to co-create AREs.

When considering energy issues and their consequences, particular attention should be paid to key factors and barriers that determine the use of and access to energy [5]. Many factors have an impact on the significant discrepancies in energy structure, energy intensity of economies, or energy prices in individual regions (the most important of which include $[6,7]$ ). Factors were selected based on a literature review:

- Geographical location and natural resources;

- $\quad$ Equipping with energy, transport, and housing infrastructure;

- Human capital;

- Equipping with capital and access to aid programs and support funds;

- Interest in and acceptance of solutions using renewable energy sources (AREs);

- The innovativeness of the economy (enterprises) and the provision of research and development facilities;

- Local, regional, and national historical and political circumstances [8].

Raw material resources are a primary factor. The resources available are an important (but not the most important) factor influencing a state's energy policy and its success. In the case of renewable energy, natural phenomena seem to be of key importance, such as the number of sunny days each year (solar energy), the number of windy days (wind energy), the number and area of rivers, lakes, waterfalls (hydropower), agricultural production opportunities, forest cover, access to waste (biomass), or geothermal resources (geothermal). Acceptance from the local community and popular for individual energy sources are also of great importance, especially in the case of wind and nuclear energy. Of course, a different group of factors is the cost of individual energy sources, investment opportunities in individual technologies (energy infrastructure), technical and technological facilities enabling the use of selected technologies, and, finally, state policy [9].

These factors, in many cases, may constitute barriers to development [10].

The costs of energy production depend on factors such as distance from raw material resources, energy infrastructure, geographic and natural conditions, technology used, etc.

The main aim of the article is to develop recommendations concerning the possibility of creating, and effectively managing, autonomous energy regions (AREs) in European Union (EU) regions. The concept of autonomous energy regions (sometimes referred to as communal energy centers) results from EU trends and regulations, including those resulting from the work on the new EU budget, showing the desire of a large part of the member states to reduce the Common Agricultural Policy (CAP) [11-18]. The European Commission's Roadmap 2050-in the form of conclusions by the European Council on building a competitive zero-emission economy (proposing a reduction of $\mathrm{CO}_{2}$ emissions by $80 \%$ by 2050) - is possible thanks to AREs [19-22]. One indirect aim of the article will be to propose methods that can be used in the process of identification and designation of preferential regions to create AREs on their territory.

The following research hypotheses have been adopted in the article: 
H1: there are natural, organizational, and social opportunities to start the process of creating AREs in EU countries;

$\mathrm{H} 2$ : local authorities are able to become local leaders in creating networks in emerging AREs;

H3: local communities (including businesses) are willing to make efforts to co-create AREs.

The objectives of this study and the hypotheses formulated above determined the method of preparation and implementation of the adopted research procedure and the manner of conducting research work.

The first priority, energy goals, is to ensure security of strategic supplies, the proper functioning of the internal energy market, and to reduce greenhouse gas emissions. Diversification of energy sources is related to the concept of an energy mix, which is a mixture of various types of energy. Their diversity increases the country's security in the event of a failure or exhaustion of one of the energy sources. The functioning of an integrated market based on economic competition is an additional aspect of creating the possibility of choosing an energy source. By promoting one's own energy resources, the independence from imported energy is a positive aspect, which has broad economic and social advantages.

\section{Materials and Methods}

\section{The Importance of the ARE Concept in Global Terms}

The energy sector in every country's economy is strategic. The competitiveness of the economy, the standard of living, and the state of the natural environment depend on its efficient and effective functioning [23-26]. The functioning of the energy sector also determines the broadly understood energy security of individual economies [27].

The dynamic changes that are taking place, whether in the political, economic, social, or environmental sphere, make it necessary to take strategic decisions and action, to rationalize the energy sectors of individual countries or regions [24]. Policies on energy resources and their optimal use should aim at the increasingly widespread construction of local energy systems based on local and regional natural, human, and capital resources. In view of the role and importance of energy for the development of economies and societies, in order to ensure the competitiveness of the economy, it is becoming necessary to begin work on building innovative energy concepts, including the construction of AREs.

For the purposes of this article, AREs have been defined by the authors as the whole or part of a given area (region), co-created by local communities, and coordinated by local government units through which energy policy is conducted, independent of the central level [22].

The ARE idea can be developed based on local resources. Due to them, the concept is not for everyone, especially large urban agglomerations that are not able to meet energy needs on their own, and very often have to attract energy from the outside. Further, in this case, investments at sea in wind farms may be an interesting issue (which is very promising) [21,26-29].

Moreover, in the case of AREs, the construction begins in small communities that are not able to cope-organically and financially-with a large investment, such as offshore wind farms. Even in local communities, wind energy (including onshore) encounters a number of barriers. The final decision depends on many conditions, and the discussed areas, according to the literature, show many benefits, for example in transport, where energy transport is often more expensive than energy production [25]. It can be noted that the transmission of energy from distant areas is also vital in the economic and financial analysis for optimal decisions when making decisions about energy sources. It is obvious that the profitability and selection of energy sources will depend on specific cases (e.g., on geographic and natural conditions) [30,31]. 
Research on the Possibilities of Creating AREs in the MazoviaVoivodeship

The research was carried out by local government units in the MazoviaVoivodeship. The following research methods and techniques were used in the research:

- $\quad$ Postal questionnaires (@);

- Taxonomic method (Hellwig's method).

The surveys, which were sent out to all local governments, were aimed at recognizing the interests of local government units in the possibility of undertaking bottom-up initiatives aimed at building energy independence in the areas in which they were located. The aim of the survey was to gain information on the openness of local societies, to the introduction of innovative methods of local and regional development management.

The taxonomic survey was conducted in order to select potential districts with favorable conditions to create independent energy regions in their areas.

\section{Literature Review}

Gussing, in Austria, was one of the first regions in the world to produce energy (for its needs) from its own natural resources and renewable energy sources. In 2007, $\mathrm{CO}_{2}$ emissions in Gussing reached $10 \%$ of 1990 emissions. The idea of the energy transformation of the village was born out of (1) the search for an alternative to the increasingly higher costs of energy production, and (2) in connection with the high economic poverty of society. Local leaders have noticed that obtaining energy was connected with the outflow of social finances to the region. It was stated that producing energy for its own use, from their own natural resources, supported by renewable energy sources, would not only make it possible to reduce the costs of obtaining this energy, but also would contribute to economic growth and a reduction in $\mathrm{CO}_{2}$ emissions, thus, contribute toward improving atmospheric air. The idea proved to be a success, not only in the field of energy, but also towards forming a network of links and cooperation between the people of science as originators and the local government-in this case, the Gussing municipality (being charismatic and forward-thinking) [32,33].

Gussing adopted strategies for the transition of the entire region towards renewable energy and energy self-sufficiency. This was achieved using equal technologies-depending on the local environmental resources available-mainly biomass and wind. The following citations indicate that the local government and determined change leaders played a key role [34-41].

There are many examples of this in all continents of the world, such as the Danish island of Samsø, which started its energy transformation in 1998 by gradually reducing its energy dependence on external coal and oil supplies to achieve full independence in electricity production in 2016 [42]. The reduction in the price of renewable energy technology in recent years has resulted in regions, such as Gussing and Samsø, finding more followers. For example, Australia is setting ambitious targets to replace conventional energy sources with technology that makes it possible to obtain energy from renewable sources. In 2016, in the Australian state of Tasmania, as much as 93\% of its energy consumption was from renewable sources [43,44].

The increase in demand for energy and the world's growing dependence on energy, which has ceased to be a luxury good, but has become an essential element for the proper functioning of the entire infrastructure around us, forces us to seek new solutions in the areas of energy extraction and consumption. The dependence of global energy on depleted fossil fuels (oil, gas, and coal), which, with the exception of gas, have a significant negative impact on the state of the natural environment, as well as individual countries depending on the supply of these fuels from external countries, shows the importance of renewable energy sources, and creating energy policies in these countries.

As a result of the rich gas deposits in Great Britain and Denmark, and convenient access to the external markets, countries, such as Ireland, the Netherlands, Belgium, Italy, Spain, and Portugal rely on gas as their main energy raw material. However, it should be noted that gas, such as other main energy resources, is one of the sources of high greenhouse gas emissions, as shown in Figure 1. However, it is 
also worth noting that the use of new technologies for both gas and coal, such as Combined Cycle Gas Turbine (CCGT) and Carbon Capture and Storage (CCS) - technology for capturing and geological storage of carbon dioxide-significantly reduce the value of greenhouse gas emissions and are close to the values of renewable energy sources (RES). This is also confirmed with the fact that the applied production and consumption technology, in which the values of the most important properties, such as efficiency, availability, and emission, as well as financial costs, are of great importance for the choice of energy source [38]. Due to the possibility of using different technologies, the diagram shows the double bars with the minimum and maximum emission values for different plant designs.

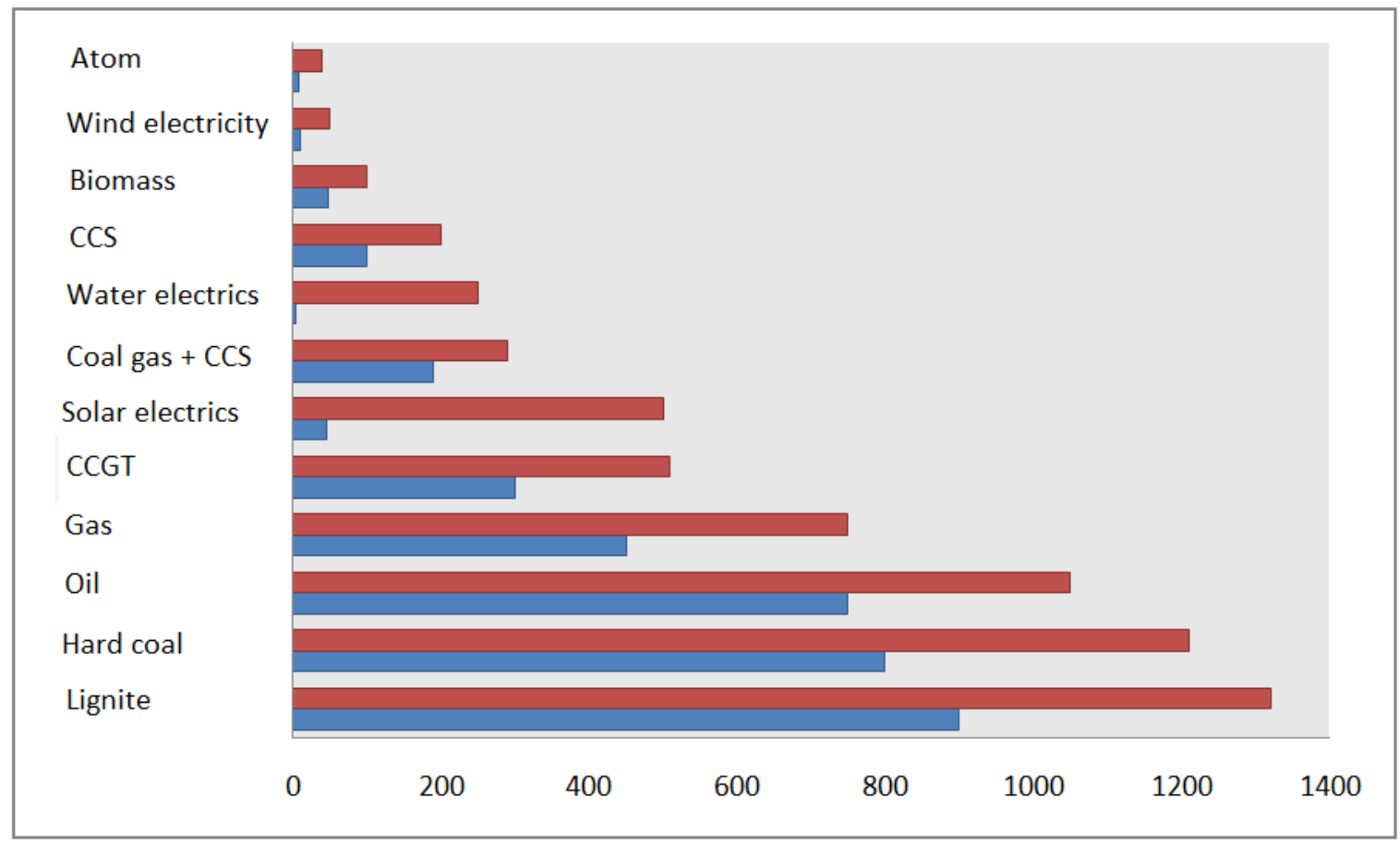

Figure 1. Greenhouse gas emissions by energy source (gram per $\mathrm{kWh}$ ). Source: own study based on: http://www.iaea.org_access: 23 December 2018, International Atomic Energy [45] Agency; www.reo. pl [46]—access: 2 December 2018; http://www.world-nuclear.org/ [47]—accessed: 15 December 2019.

The positive image of AREs in highly developed countries has been deeply rooted in the mentality of societies, and, as a result, has become the basis for indicating the direction of development of the energy sector [48]. In addition to regions, entire countries (e.g., Denmark) are already taking action to being self-sufficient in energy; self-sufficiency is based mainly on renewable sources of energy [49]. Increasing access to technology has led to an interest in producing energy from renewable sources for building independent energy regions in highly developed countries, as well as in countries with a much lower level of development (e.g., China and India). In China, in 2016 alone, more than 35 GW of electricity generation capacity using solar energy was installed. The interest in using technology to obtain energy from RES is not only the result of problems related to air pollution (it is estimated that, in China, more than 1.1 million people die every year from smog), but also from the huge development of a country's economy and the creation of new jobs (thanks to the use of this technology) [47].

Countries, such as China or India, which dynamically develop conventional energy thanks to huge coal resources, also invest in renewable energy, which proves that they understand the risks associated with it in the long-term. It is about long-term pollution of the environment, and, on the other hand, they are aware of the depletion of conventional resources. This shows a development path for AREs that will not be dependent on external supplies (often from other countries, which is undoubtedly used in political pressure in peacetime, not to mention the dangers of wars). 
When analyzing the emissivity of economies, one should look at the global importance of the EU in this matter. The data below clearly show that the entire EU, despite the sixth position of Germany in the world (in terms of $\mathrm{CO}_{2}$ emissions), has no significant impact on global emissions [50]. Therefore, only through its own actions to reduce $\mathrm{CO}_{2}$ emissions in the EU Member States, is it impossible to influence global changes (Figure 2).

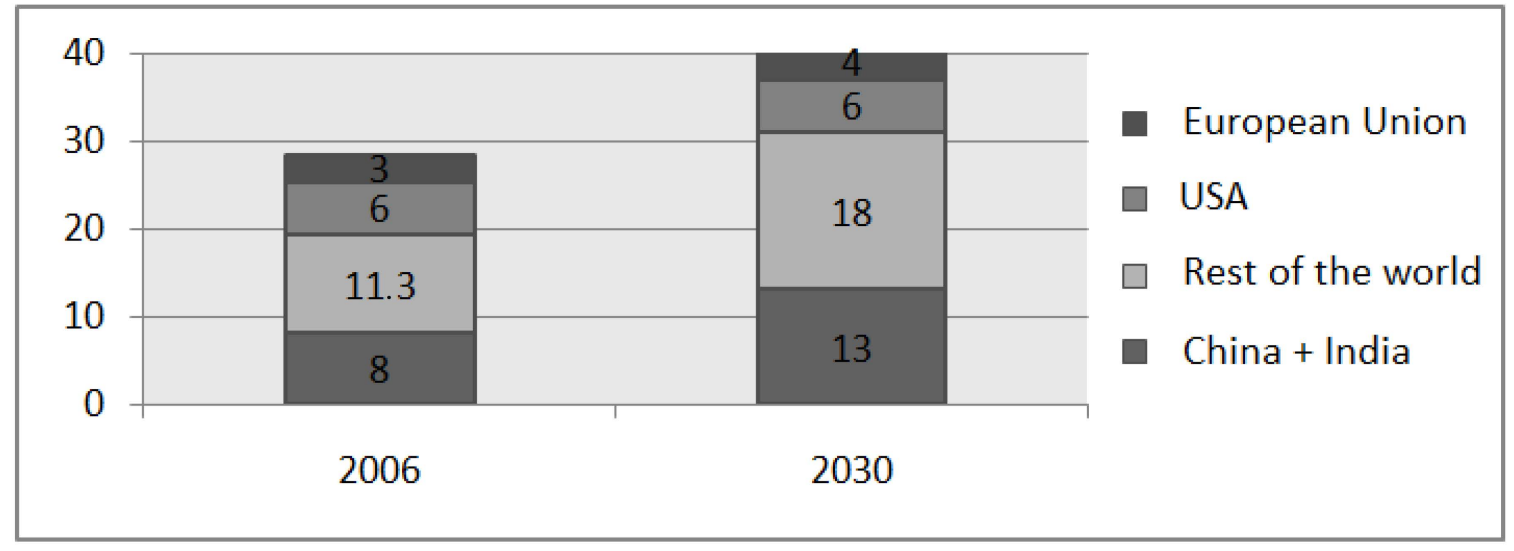

Figure 2. $\mathrm{CO}_{2}$ emissions (billion tons). Source: Ernst \& Young, 2016; Enerdata [51], Global Energy Statistical Yearbook $2018[52,53]$.

AREs are developing dynamically, especially in highly developed countries [51], which have been successfully developing innovative concepts of energy systems for many years. Case studies show that the solutions adopted in individual energy regions have a significant positive impact on socioeconomic development [52]. Therefore, the process of creating AREs should include the following steps:

- $\quad$ Identify and assess the potential of different forms of energy in a given area;

- $\quad$ An estimate of the current and future energy needs of the area;

- $\quad$ An estimate of the real degree of security of energy needs from local sources;

- The selection of a supplier of complementary energy;

- Draw up local energy development programs;

- Inventory and assessment of the technical condition of local/regional energy infrastructure, networks, and consumers;

- Take initiatives to set up local businesses involved in the preparation and implementation of projects related to the functioning of AREs;

- Promotion of AREs and their applications;

- $\quad$ Building a network of links between the entities of the energy system and establishing cooperation with other AREs.

The construction of the ARE is, in its fundamental issue, energy-oriented, but it also significantly affects the social and economic development of the entire area within its scope of influence (especially in the area of construction, transport, or production, including, among others, the agricultural area).

In order to build the ARE effectively, it is necessary to take active measures in many areas of social and economic life. In this respect, the role of local and regional self-government units, which have the possibility of influencing local and regional development as part of their own public tasks, and aim to satisfy the needs of the self-government community, become important [53,54].

Analyzing the development conditions of Central and Eastern European countries (CEECs), on the one hand, significant similarities should be taken into account (which undoubtedly include historical conditions or development ambitions) [55]. On the other hand, differences (cultural, religious, social, economic, or environmental) should be taken into account. Undoubtedly, the common point that links all countries is the process of integration into the EU, which, for all CEECs (with the exception of 
Albania) has ended in full membership of the community. The drive for integration into the EU has forced the adoption of many environmental regulations, which also clearly translated into CEECs' energy sector [56].

A sustainable low-carbon economy can contribute to dynamic development. This is mainly indicated by the compromise within the "triad of goals", which indicates that a low-carbon economy will be the optimal long-term choice. The energy policy of EU countries, setting out national strategies in this area, focused on the implementation of three goals [57]: (1) minimizing energy prices while ensuring the conditions for self-financing of the sector; (2) ensuring an appropriate level of energy security in the short and long term; and (3) minimizing the environmental consequences of the operation of energy technologies (Figure 3).

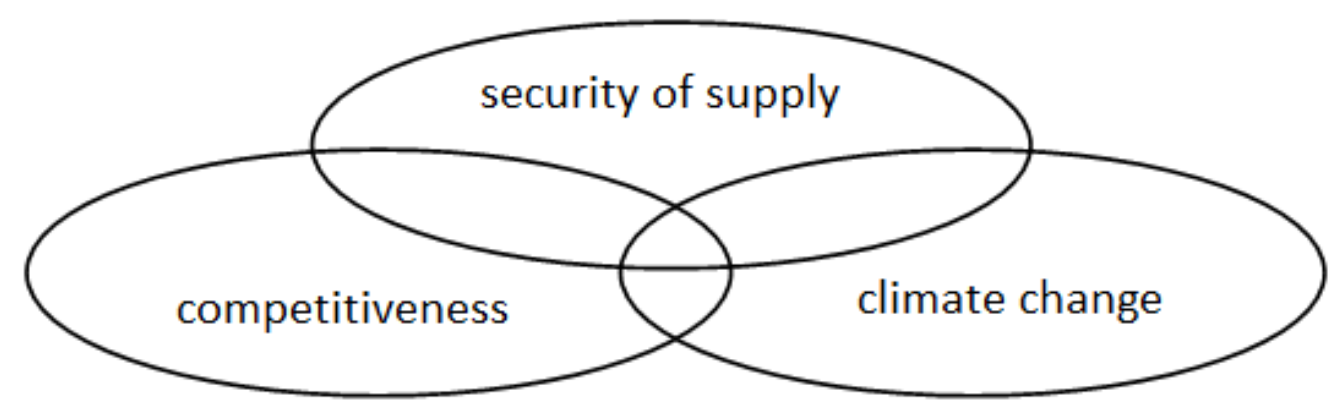

Figure 3. The triad of goals of the European Union (EU)'s climate and energy policy in the 2030 perspective. Source: own study.

However, in many fields these goals are mutually exclusive and antagonistic, because both the implementation of technologies for reducing greenhouse gas emissions and increasing security through the diversification of fuel and energy supplies are expensive. In the current state of development, non-emission technologies are particularly expensive, which is not in line with the competitiveness strategy. In addition, taxes that in the EU often exceed the price of the energy supplied should be taken into account. An additional problem is the inconsistency of the tools for optimizing energy sources in the short and long term, because, although the benefit of introducing market mechanisms to the energy sector is not questioned, they focus on generating profit and optimizing resource allocation in short time horizons. Therefore, the market is not a source of strategic solutions and the role of the creator of the energy policy must be retained by the state or supranational structures. This border between the market and the state changes with the evolution of views on the role of strategic sectors, among which, the energy sector plays a special role as a fundamental sector, influencing prices in the economy, and, thus, directly on the economic development of the member states. As a result of the double crisis (financial and political-energy) and due to the controversy and the lack of compromise among the EU member states, as to the effectiveness and importance of the costly effects of climate protection, economic priorities have been recognized as the most important. Therefore, at present, the European Commission has expressed the conviction that economic competition should play the greatest role in the process of energy market integration. However, as part of the integration of the EU energy market, there are many problems that need solving, including fiscal differentiation, lack of technical harmonization of infrastructure, and different approaches of EU member states to environmental protection. The EU is increasingly dependent on imported oil and gas, while the demand for these raw materials continues to grow. Therefore, the greatest challenges for EU Member States include the lack of diversification of energy sources, as well as the issue of security of supply, which is directly related to external actions taken by the EU in relation to the most important suppliers of energy resources. At the same time, member states face the need to build competitive internal energy markets and increase energy efficiency. The European Union is increasingly exposed to the impact of fluctuations and rising prices in international energy markets, and to the consequences of the increasing concentration of energy resources among the world's few countries. As part of increasing the security of energy supply, 
the EU is taking measures to reduce its vulnerability to external factors resulting from dependence on imported hydrocarbons, and is looking for solutions that will support employment and economic growth in the EU, which will ensure security of energy supply to consumers at affordable prices. Therefore, within the EU, the use of one's own, available energy resources is promoted, in Central and Eastern Europe (coal, and investments in renewable energy sources). A common area with concern for climate change is obtaining energy from one's own resources as part of clean coal technologies [58], gas, and other energy sources [59-63].

Undoubtedly, historical circumstances are an important factor influencing the development of the energy sector in this part of Europe, including dependence on fossil fuel supplies from the Russian Federation [41]. A common problem is the poor technical state of the energy infrastructure, requiring huge replacement investments, which the countries in this group do not have at their disposal [42].

In addition, a huge social problem is related to the lack of willingness among citizens and companies to take pro-innovation measures. Negative trends are also compounded by the habits of energy consumers, which are revealed by the lack of a habit of saving both energy and natural resources. Another stigma that this group of countries is facing is the relatively low level of knowledge and public awareness of environmental protection. In addition to these problems, there are economic problems resulting from the much weaker economic condition and lower level of development of the CEECs compared to other EU countries. Table 1 presents statistical data on CEECs, in terms of energy needed to produce a unit of GDP (Gross domestic product), and the share of renewable energy in final energy consumption.

Table 1. The importance of energy for the economy.

\begin{tabular}{cccccc}
\hline \multicolumn{2}{c}{ Energy Intensity of GDP in Chain Linked Volumes } & \multicolumn{3}{c}{$\begin{array}{c}\text { Share of Renewable Energy in } \\
\text { Final Energy Consumption }\end{array}$} \\
\hline \multicolumn{2}{c}{ Kilograms of Oil Equivalent (KGOE) Per Thousand Euro } & \multicolumn{3}{c}{$\%$} \\
\hline Geo $\backslash$ Time & $\mathbf{2 0 0 5}$ & $\mathbf{2 0 1 7}$ & $\mathbf{2 0 0 5}$ & $\mathbf{2 0 1 7}$ & Target for 2020 \\
\hline European Union-28 countries & 153.5 & 121.0 & 9.1 & 17.5 & 20 \\
Bulgaria & 627.7 & 426.2 & 9.4 & 18.7 & 16 \\
Czech Republic & 327.8 & 238.5 & 7.1 & 14.8 & 13 \\
Estonia & 359.1 & 317.0 & 17.4 & 29.2 & 25 \\
Croatia & 224.2 & 186.0 & 23.7 & 27.3 & 20 \\
Latvia & 266.0 & 213.0 & 32.3 & 39.0 & 40 \\
Lithuania & 337.5 & 209.9 & 16.8 & 25.8 & 23 \\
Hungary & 285.4 & 230.1 & 6.9 & 13.3 & 13 \\
Poland & 324.0 & 228.4 & 6.9 & 10.9 & 15 \\
Romania & 354.2 & 205.6 & 17.2 & 24.5 & 24 \\
Slovenia & 220.8 & 173.5 & 16.0 & 21.5 & 25 \\
Slovakia & 348.9 & 211.2 & 6.4 & 11.5 & 14 \\
Albania & 323.5 & 228.1 & 31.4 & 34.6 & - \\
\hline
\end{tabular}

Source: Own study based on Eurostat data, http://ec.europa.eu/eurostat [61] [access: 31 December 2019].

There is great diversity and disparity in the approach to economic transition-and, thus, to the energy mix, access to raw materials, the provision of energy infrastructure, or the approach of the community, and the political class to energy problems-between the CEECs, the regions, but also between individual areas within regions. As can be seen from the analysis of data in Table 1, there are significant disparities in the energy intensity of individual economies. The economies of Slovenia and Croatia are the most efficient. When analyzing data on the energy intensity of individual economies in the CEECs, it should be noted that there was a significant improvement in all countries, in terms of the indicator under consideration between 2005 and 2017.

In the case of the share of renewable energy sources in the energy mix of individual countries, the situation also varies greatly. Latvia is the unrivalled leader in this respect, where the share of energy from renewable sources in 2017 was 39.0\%. It should be noted, at this point that, in many 
countries (Bulgaria, the Czech Republic, Estonia, Croatia, Lithuania, Hungary, and Romania), in 2017, the Directive's target to be achieved by these countries in 2020 was exceeded. The lowest share of energy produced from RES was in Poland in 2017 (10.9\%).

\subsection{EU Energy Policy Acceptance of the ARE}

The most widely accepted definitions of sustainable development presents sustainable development as one in which the needs of the current generation can be met without compromising the chances of future generations to meet them. The basic condition for the idea of sustainable development is to guarantee a high quality of life for current and future generations, while making rational use of available resources [45]. "This approach is dominant in international economic relations and, in recent years, has focused on the need to transform social and economic systems into a green economy" [26]. One of the indicators characterizing sustainable development includes energy self-sufficiency, defined as the ratio of the amount of energy obtained to the amount of energy consumed in a given country/region. In this regard, the method and technology of obtaining and using energy-especially its impact on the environment-is of particular importance. The European Council expressed its views on this in detail, noting that, "EU energy policy must ensure security of energy supply for households and businesses at reasonable and competitive prices and costs, in a safe and sustainable manner. This is particularly important for Europe's competitiveness, given the growing demand for energy in major economies and the high prices and costs of energy" [64]. All member states and EU institutions are responsible for shaping the energy policy adopted and implemented. This is determined by Article 194 of the Treaty on the Functioning of the EU, which introduces a legal basis governing the activities of the EU and the member states in the field of energy. The European Commission has presented a number of objectives for the member states, the implementation of which will be necessary to implement energy policy, namely [65-67]:

- Guaranteeing Europe's electricity supply;

- Ensuring that energy prices do not act as a brake on European competitiveness;

- Environmental protection and in particular the prevention of climate change;

- Developing energy networks.

At the same time, it has been pointed out that member states are free to invest in the energy sources of their choice, but must take into account European targets for energy efficiency, renewable energy sources, or atmospheric pollution. In terms of objectives, the European political strategy currently being implemented is based on the Third Energy Package, adopted in 2009. The objectives of this package are also included in the strategy "Europe 2020" and it was named "Programmer 20-20-20" [66]. It follows from Directive 2009/28/EC that the EU as a whole should achieve by 2020 a $20 \%$ share of energy from RES in total energy consumption and a 10\% share of this energy in transport. The directive also sets out national mandatory targets for each member state. The results of the measures taken to date in this area show that the EU has a chance of achieving its objectives for 2020. However, the future of EU energy policy after 2020 has been defined, among other things, in the Energy Roadmap 2050 [68]. The document sets out a framework for action in the energy sector. The primary objective is to further reduce greenhouse gas emissions and, closely related to this, measures to increase the share of renewable energy in the EU energy mix.

The European Energy Security Strategy proposed by the European Commission, which is intended to be an integral part of EU energy policy until 2030, is of certain significance for the shape of EU energy policy. The implementation of the assumptions adopted in the document is intended to strengthen the EU's resilience to energy crises, reduce dependence on individual fuels and energy suppliers, and increase energy production in Europe [69]. As part of the European energy security strategy, traditional measures have been proposed, such as the diversification of energy supplies and carriers, creation of the internal energy market, modernization of existing energy sources, searching for new energy technologies, and looking for opportunities to lower energy purchase prices. However, 
innovative activities aim at a creative and innovative approach to energy consumption, redistribution, acquisition, or transfer. Introduction of technologies aimed at environmental protection, creation of a common energy market with areas outside the EU, education, and upbringing of young people, emphasizing respect for the principles of saving energy sources and disseminating information about the possibilities of obtaining electricity and heat from renewable energy sources, can play a huge role in the undertaken activities innovative. An important role in this respect may also be played by innovative approaches to the creation of organizational structures allowing for the organization of production, distribution, and use of energy in a new way, in particular for energy distributed using local and regional renewable resources.

\subsection{Impact of the ARE on the Socioeconomic Development of the Regions}

An inherent feature of the functioning of modern countries and societies is the desire to create conditions for better meeting the needs of society, which, at the same time, translates into an improvement in the quality of life. These actions are reflected in activities supporting economic growth, which is defined as a continuous process leading to an increase in the productive potential of the economy and, therefore, an increase in the product produced in it. Regardless of the economic growth models considered in the literature on the subject (Keynesian models, e.g., R.F. Harrod, E.D. Domara, N. Kaldor), neoclassical models, (e.g., R.M. Solowa, E.S. Phelpsa, K. Shella), real business cycle models (e.g., G.D. Hansen), endogenous growth models (e.g., R.E. Lucas, P.M. Romer, R.J. Barro) assume a constant increase in production of goods and services.

Global economic growth, driven, inter alia, by integration and globalization processes, is characterized by an increase in demand for electricity, heat and fuel. Therefore, increasing energy consumption is contributing to increased environmental pollution, the exploitation of energy resources and significant climate change. Access to sustainable energy has ceased to be a luxury good and has become a key and indispensable element for economic growth.

EU countries, regions, and local and regional authorities are now facing the need for an energy transformation that will provide certain stakeholders with access to cheap, stable, secure, and environmentally friendly energy. Regions that take up the challenge of achieving energy autonomy should consider many aspects, such as political decision-making processes, the role of citizens, changing the sociotechnical system, energy use of land, and sustainable spatial planning.

The transformation of the energy system in AREs require a change in social and technical processes and a transformation of their management. Stakeholders from different areas of society are involved in the process of change and they influence the organization of the transformation process in different ways. The persons/entities involved in the initiative form a network of interconnections representing the welfare of different stakeholder groups. When developing the ARE strategy, it is necessary to create a model for the transition process to a new local energy system based on sustainable development, taking into account not only the effects of climate change mitigation, but also the economic development of the affected area.

The energy transformation does not only entail a change in technology, but also a social change in the lifestyle of the people living in the region. Therefore, the dispersed generation ceases to be just a technical issue and becomes "... part of the philosophy of energy supply in the future and offers an opportunity to overcome global disbelief in the ability to ensure energy security and the resulting lack of confidence in investing in new generation capacity. Distributed generation using local energy resources is a pillar of local energy markets, particularly evident where multi-energy companies are established".

The development of the ARE means a paradigm shift in the energy sector, understood as a gradual transition from conventional to distributed energy, in which the society occupies a completely new role, unknown in modern history, that of producer and consumer of energy, with responsibility for the private and common good. Changes should be made systematically by demonstrating good practice 
and then changing the whole social and technical system. The initiative to build the ARE stimulates local institutional, administrative, social, intellectual, and financial capital.

\section{Results}

\section{Analysis of the Survey}

The survey was conducted from 13 February, 2018 to 26 June, 2019. The questionnaires were sent in an electronic version to all municipalities of the MazoviaVoivodeship. Out of the total number of 314 municipalities in the MazoviaVoivodeship, 145 were answered. The aim of the conducted surveys was to examine how local communities were prepared for the introduction of the ARE, what was the state of knowledge on the subject, and what was the potential level of absorption of innovative solutions among local communities. Surveys, such as most indexation methods, are not perfect. The information obtained in this way is tainted by the subjectivity of the respondents to the questionnaire. Therefore, when interpreting the information received, it is advisable to use moderation and rationality in order to inhibit the tendency to make quick generalizations. However, it should be pointed out that the number of surveyed municipalities, in the case of a high convergence of answers, indicates their similarity in the areas under investigation, which allows for the formulation of credible conclusions.

The following answers were given to the questionnaire questions:

Is there a municipal development strategy in your area where the development of energy from renewable sources is indicated? (Figure 4).

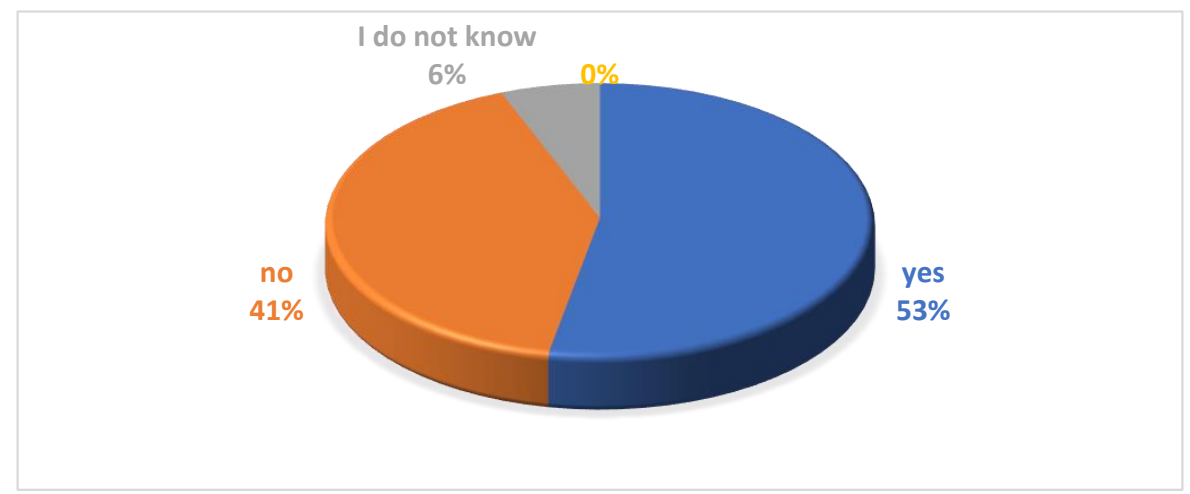

Figure 4. The development strategy of the commune in the area marked as indicated as the development of renewable energy.

The results of the research in this area point to a coefficient of $41 \%$, which indicates that so many surveyed communes do not have a strategy for the development of energy from renewable sources.

Do you have land that can be used for investments in renewable energy sources? (Figure 5).

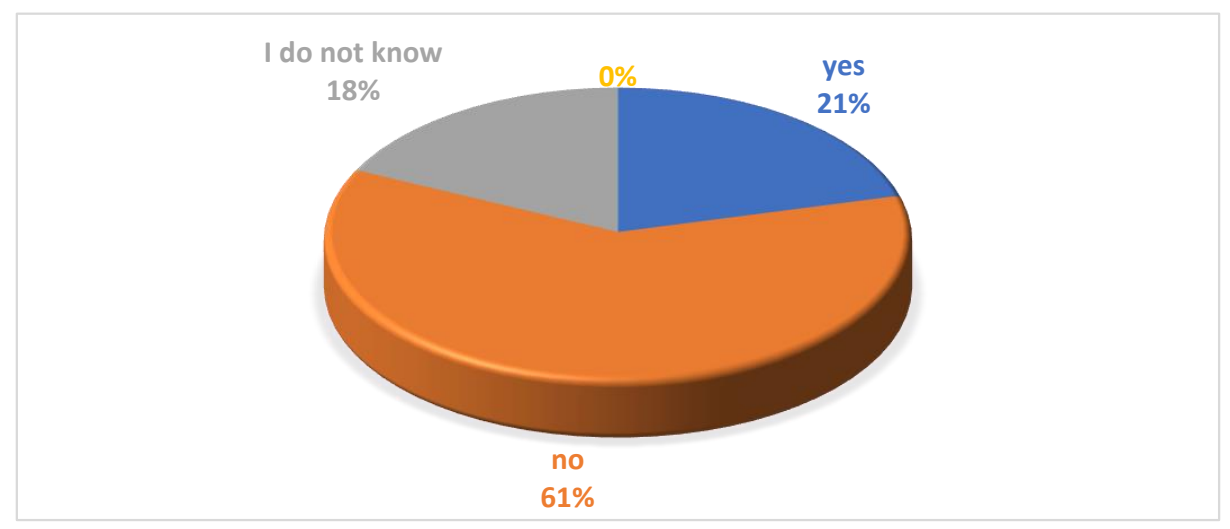

Figure 5. The land is a field to be used for investments in renewable energy sources. 
The answer to the question related to the possibility of allocating land for investments should be linked to the structure of the answer to question 1-here, in turn, more than half of the surveyed municipalities declare that they do not have any land that can be allocated for RES investments.

Has your municipality established a low-carbon economy plan for this or next year? (Figure 6).

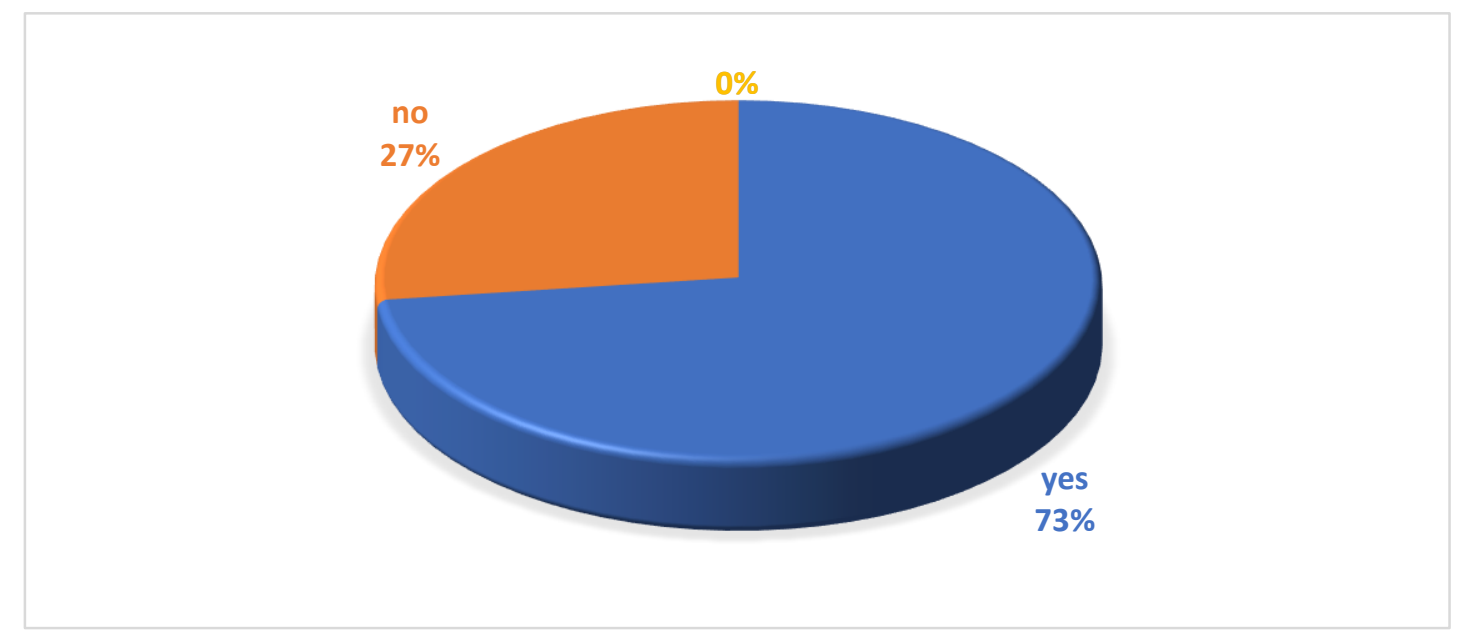

Figure 6. Development of a low-emission economy map by the commune (for this or this year).

With what means do you want to achieve the objectives of the low carbon economy plan? (Figure 7).

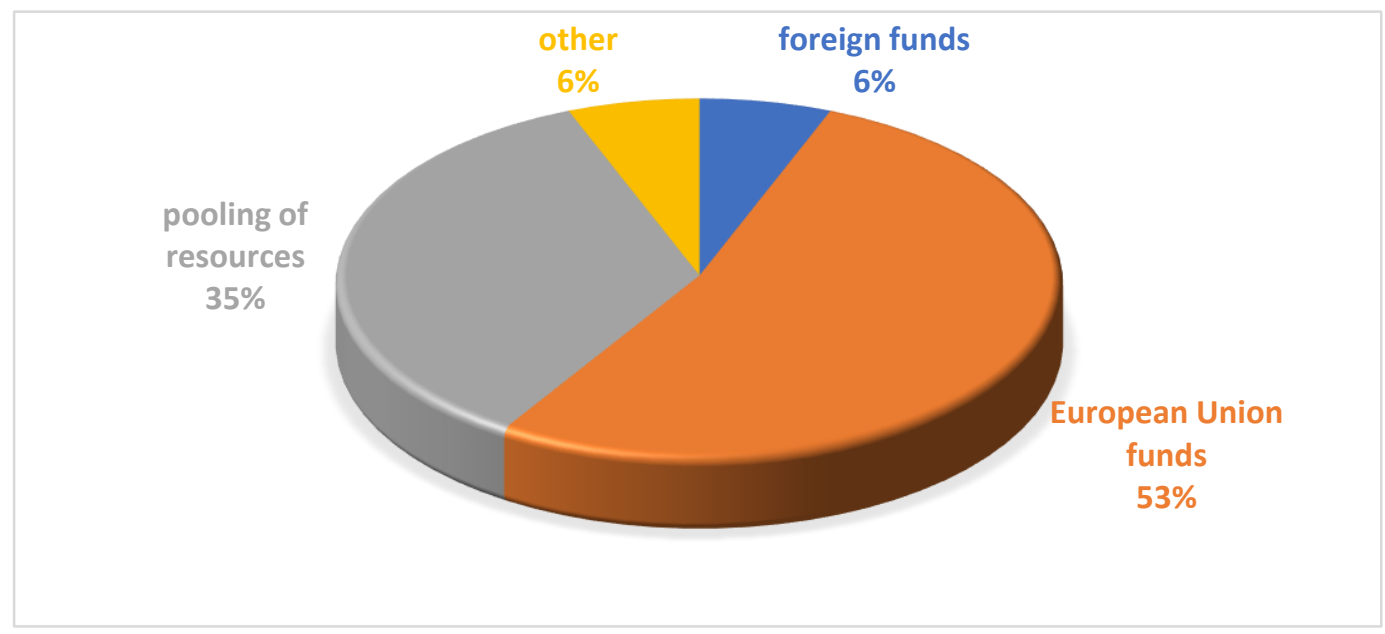

Figure 7. The means by which the goals of a low-carbon economy are achieved.

When analyzing the answers to questions III and IV (which coincide in their subject matter), it should be noted that the majority of the surveyed municipalities (73\%) have developed plans for a low-carbon economy, and the sources of obtaining funds for this purpose are extremely interesting-EU funds dominate here, as well as combining other, mainly national, sources of funding. This approach to the problem allows us to believe that the low interest in creating the ARE is not due to a lack of funding sources, but is a result of other, non-financial factors.

Who is the largest energy consumer in your municipality? (Figure 8). 


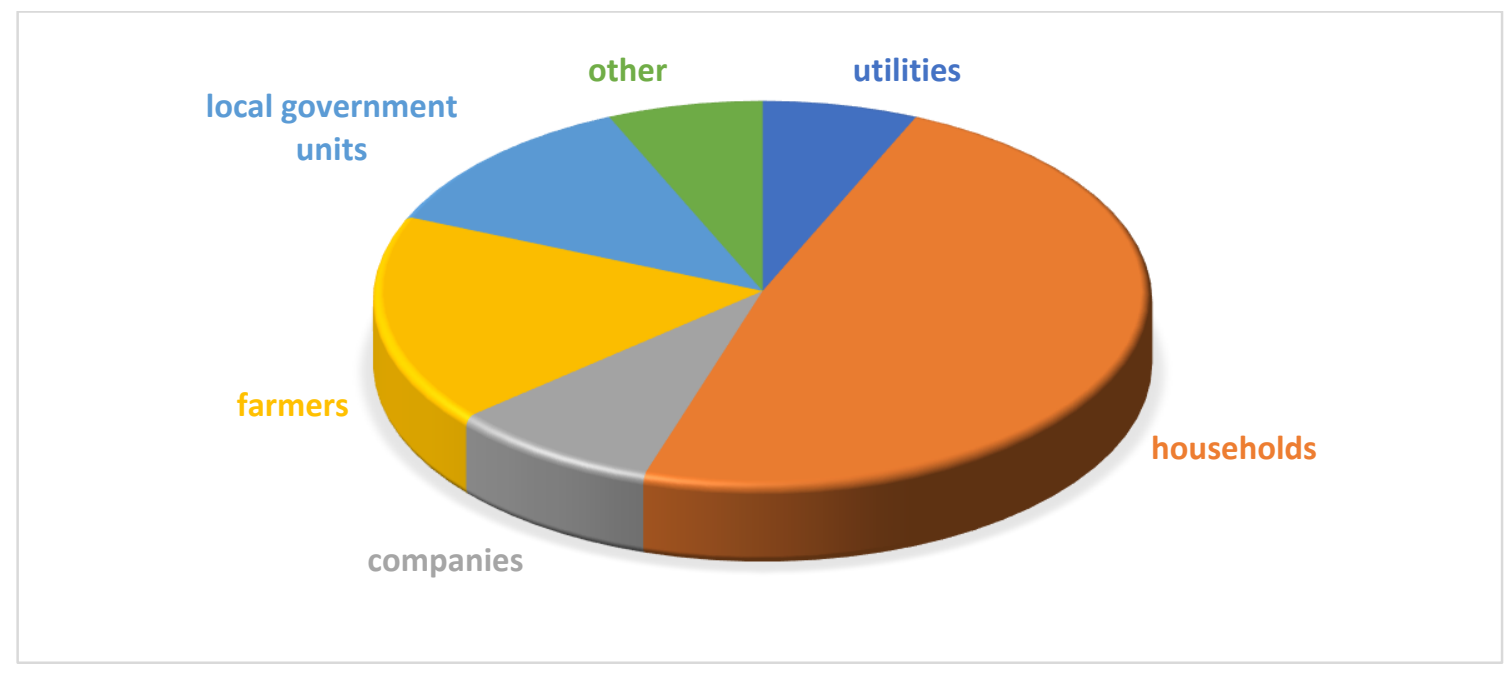

Figure 8. The largest consumer in the commune.

The analysis of the answers to question $\mathrm{V}$ leads to surprising conclusions: contrary to popular opinion, it is not companies but households that constitute the largest group of energy consumers, which, in turn, allows us to conclude that the ARE concept should be promoted among the public at a local level.

Are you interested in taking action to switch to cleaner rolling stock (purchase of electric cars) in your municipality? (Figure 9).

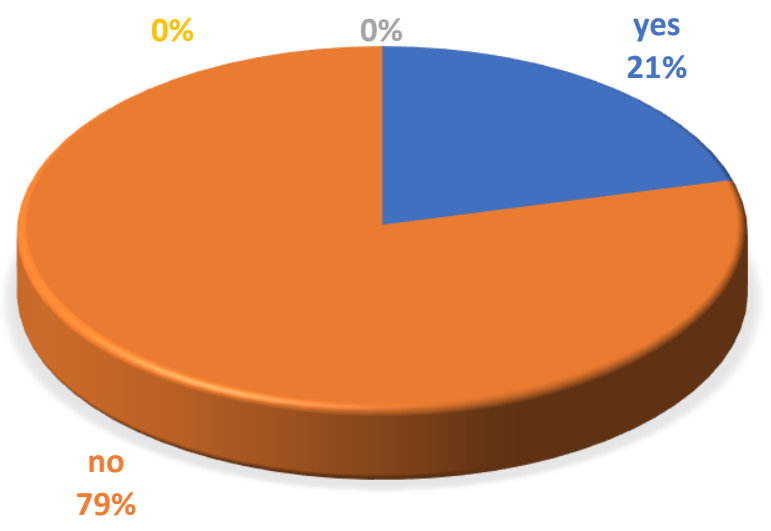

Figure 9. Interest in tools to switch to cleaner rolling stock (car purchases).

Unfortunately, the inhabitants of the municipalities are not interested in changes related to the sources of this state of affairs should be found in the relatively high prices of such vehicles and the lack of state action to motivate society to replace vehicles with electric ones.

For the purposes of this study, low emissions in Poland were defined as: dust and harmful gas emissions at heights of up to $40 \mathrm{~m}$. These pollutants come from domestic heating ovens and local coal-fired boiler houses, in which coal is burned in an ineffective manner, and from combustion gases. A characteristic feature of low emissions is that it is caused by numerous sources introducing small amounts of pollutants into the air.

Is there air pollution caused by low emissions in your municipality? (Figure 10). 


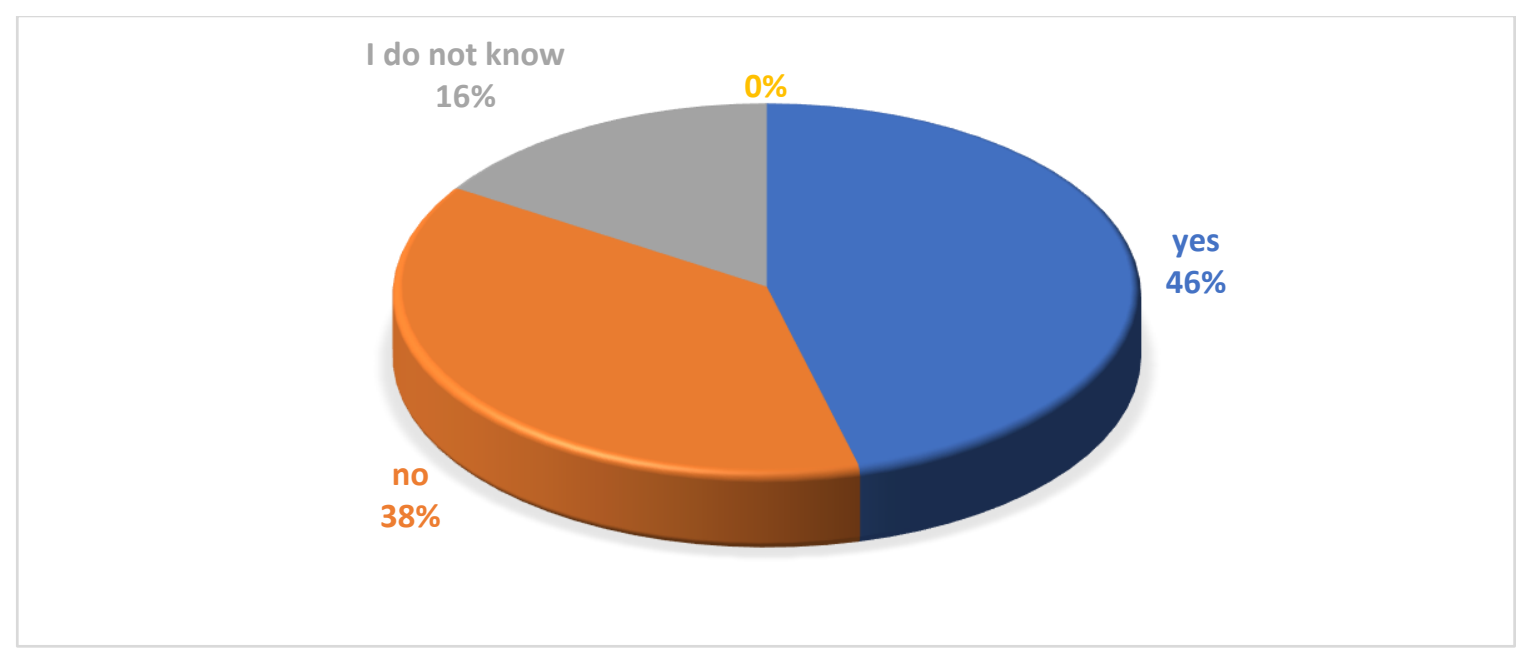

Figure 10. Occurrence of air pollution production with low emissions.

As it results from the analysis of the answers to Question 7, it should be noted that more than half of those surveyed see the phenomenon of air pollution as a significant social threat. It is also worth emphasizing that the problem of air pollution is still progressing, which does not translate directly into a positive perception of the ARE in local communities.

The predominant energy source in your municipality is: (Figure 11).

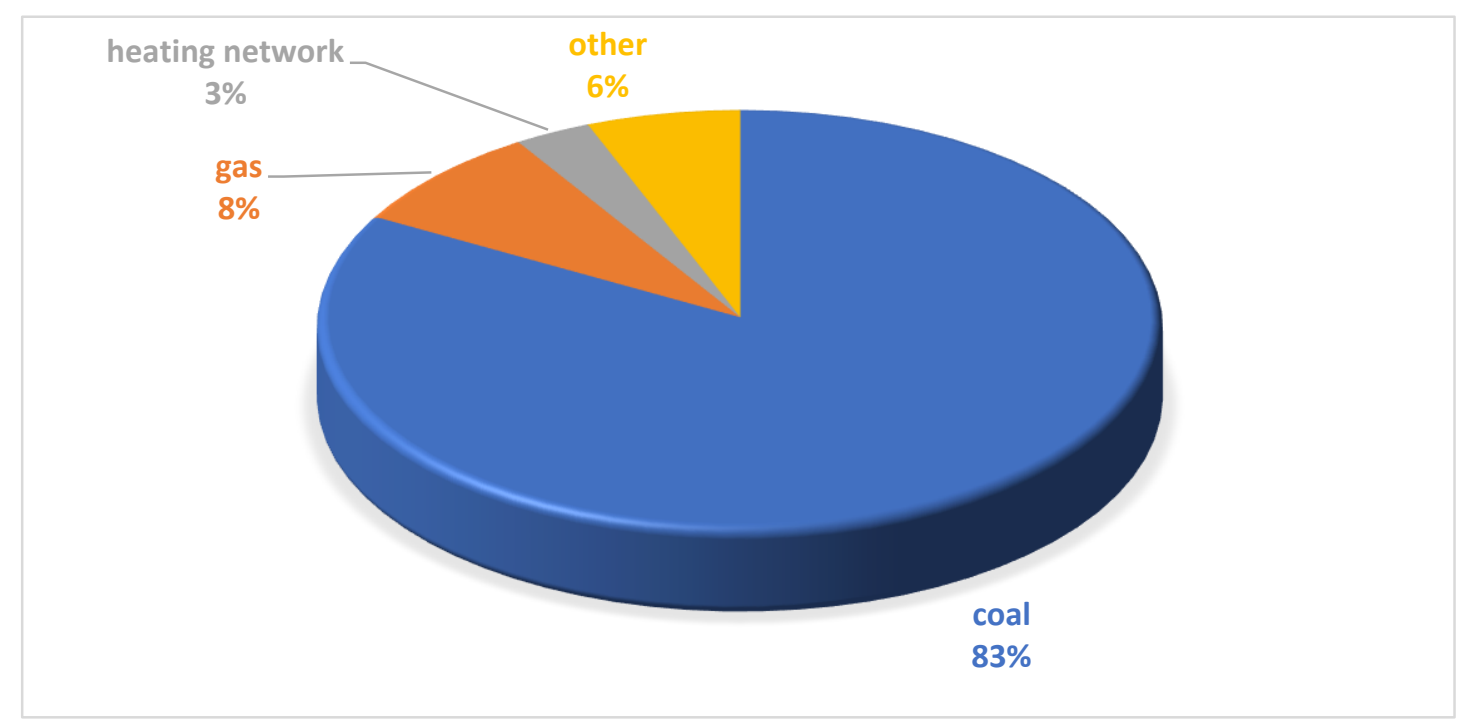

Figure 11. Dominant energy sources in the commune.

The municipalities surveyed indicate that more than $83 \%$ of energy is produced from fossil sources, i.e., coal. This is undoubtedly a result, which forces us to recommend solutions, which will lead to a reversal of these proportions in favor of renewable energy as soon as possible.

Are there renewable energy installations in your area?

Yes-73\%

No- $-27 \%$

If so, please choose the type of renewable energy sources. If the answer is indicated, Question 10 should NOT have been omitted (Figure 12). 


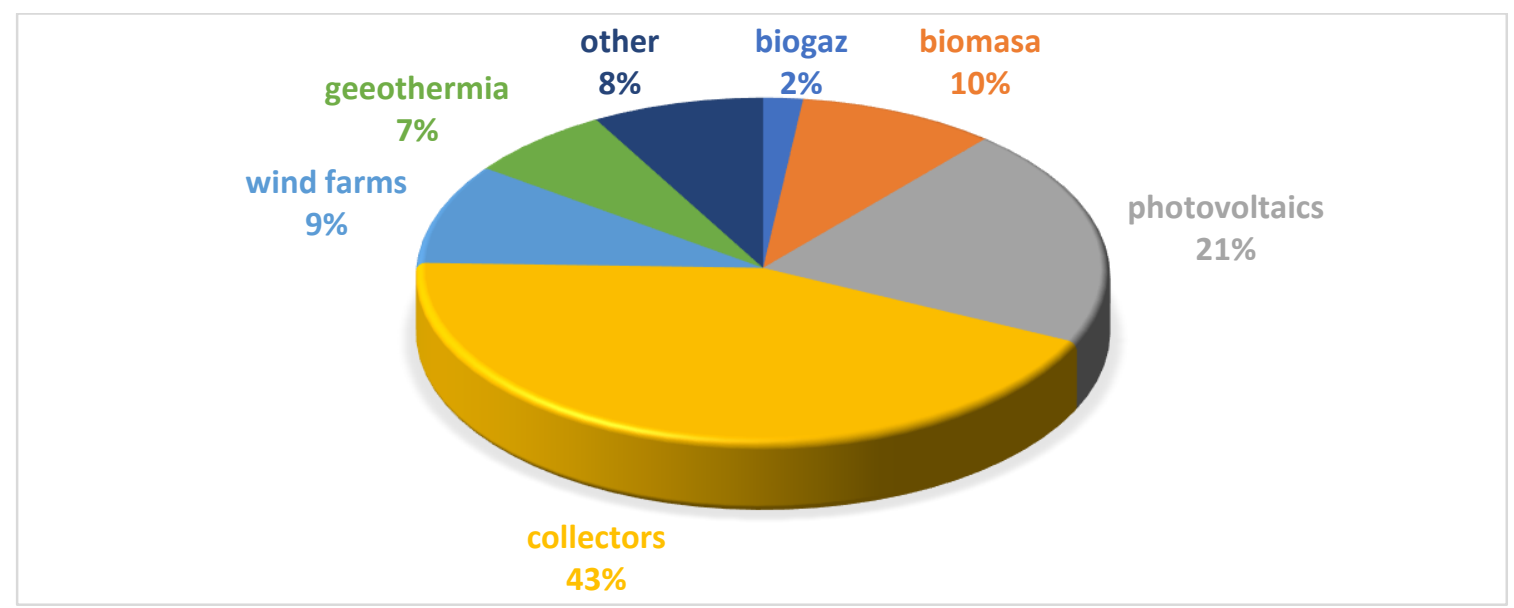

Figure 12. A type of renewable energy.

Analysis of the answers to the question is not surprising-solar collectors and photovoltaic installations dominate, which suggests that these installations dominate in households, public institutions (e.g., schools) and small businesses-these installations are installed at relatively low cost and their efficiency is also limited.

Do you support possible investments in renewable energy sources in the municipality? (Figure 13).

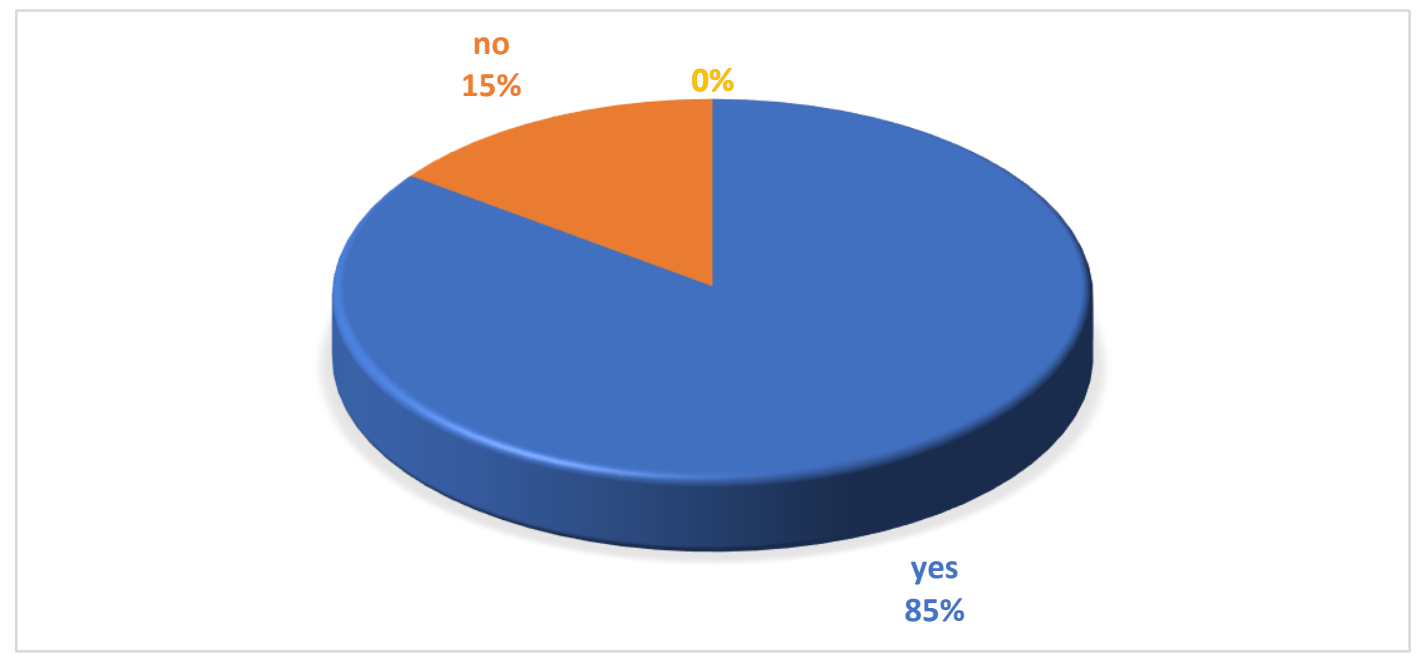

Figure 13. Support for investments in renewable energy sources in the commune.

Respondents are clearly in favor of new investments.

In the case of renewable energy sources, which stands in some contrast to previous answers, it must be concluded that this perception of the problems of renewable energy is, and will continue to be, the result of an ever-increasing information and promotion campaign on this issue.

Are you interested in the possible acquisition of energy from renewable sources for the municipality's own needs, e.g., for lighting? (Figure 14). 


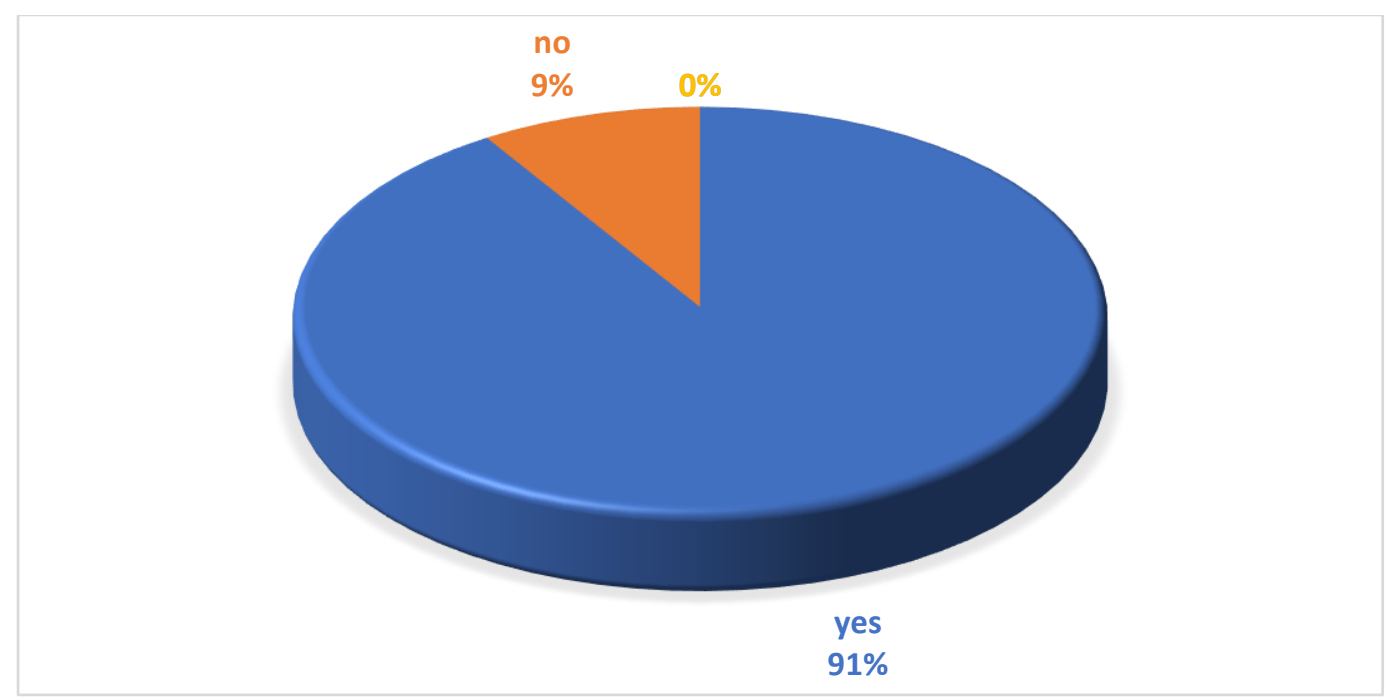

Figure 14. Possibility of obtaining energy from renewable sources for the commune's own needs.

The structure of the answer to the question formulated in this way is encouraging, as it proves that local communities will exert influence on their authorities to invest in renewable energy sources.

According to the surveys carried out, the basic barrier to implementing the concept of energy self-sufficiency is not so much a lack of own financial resources as has been thought so far. The main barrier is the low demand and supply of innovative services and technologies-the solar collectors are still dominant technology of renewable energy sources that are used to obtain energy needed for hot water preparation. This is, for the global technological possibilities, too narrow a range of RES applications in Poland.

The main motivators for the initiatives related to investments in renewable energy sources for local government representatives include the reduction of operating costs, which are a significant burden for municipal budgets and the improvement of air quality. Reducing pollution in a given area by replacing installations fueled with solid fuels, electricity production (coal), or means of transport (oil) with renewable energy sources contributes to the improvement of air quality. The propagated plan to reduce the negative impact of the energy sector on the environment and enter the path of sustainable development of the world's countries. This is a challenge from climate change due to greenhouse gas emissions, a significant cause of which are emissions from energy companies [69-71].

The next criteria of the above initiative are to ensure energy security, pressure from society, and increase the attractiveness of the region. Legal requirements or profit-making activities are marginal criteria for selection of RES investments.

\section{Description of Taxonomic Method and Test Results}

Taxonomic methods prove very useful in research into the competitiveness of economies, cities, or regions, including the issue of sorting out a particular set according to many characteristics at once. The use of these methods in regional and local studies is particularly justified, as they allow for the multi-characteristic classification of spatial units. The use of taxonomic methods results in synthetic measures, the most important aim of which is to "order" objects according to the level of a multi-characteristic phenomenon. The construction of the measure takes into account all the diagnostic variables, but depending on the method adopted, their impact on its value may vary. This also applies to the interpretation of obtained results. The conducted research procedure, referring to the applied taxonomic methods, consists of the following stages:

1. Selection of diagnostic variables.

2. Standardization.

3. Replacement of the destimulant with stimulants. 
4. Calculation of synthetic indicators.

5. Interpretation of obtained results.

The selection of variables is a very important stage in taxonomic research, on which the final results depend to a large extent. When selecting the variables, we should keep in mind the aim of the research and the selection of characteristics in a manner that ensures the best possible measurement of the phenomenon under investigation. The next stage of research is the standardization procedure, which allows non-comparable values to be transformed into relative and comparable values. Different methods of standardization are known, e.g., variable value-arithmetic mean/standard deviation, or: variable value/standard deviation or variable value/arithmetic mean. The next step of the test is to replace the destimulant with stimulants. This can be done by using one of the formulas: $X^{\prime}=1-X_{i j}$ or: $X^{\prime}=1 / X_{i j}$; or: $X^{\prime}=-X_{i j}$, where: $X_{i j}$-the destimulant value for $i$-th is implementation of the variable for $j$-th is facility, $X_{i j}$ - the value of the destimulant converted into a stimulant. The next stage of the research is to calculate a specific taxonomic method and then to interpret the results obtained [72]. The method uses the statistical data published by the Central Statistical Office and published in the Regional Data Bank (www.stat.gov.pl).

The process of constructing a development measure using the Hellwig's method begins with determining the elements of the observation matrix, i.e., the value of the features $X j(j=1,2, \ldots, m)$ corresponding to individual sites $O i(i=1,2, \ldots, n)$.

1. Four indicators have been selected for the study, which have been considered crucial by the Delphic Method research team. The study was carried out based on statistical data for 2018 (last year for which statistics were available). These included the following indicators:

- $\quad$ Registered unemployment rate in \%.

- Use of the gas installation in \% of the total. Income of the district per 1 inhabitant. Average gross monthly salary. Justification for the choice of indicators by the research team.

- $\quad$ Registered unemployment rate in \%-the high level of unemployment in a given region creates developmental opportunities. According to the analysis of world literature, research and good practice analysis [73], renewable energy is an economic sector that creates many jobs. Labor resources provide an opportunity and allow us to presume that a significant proportion of people will be interested in taking up employment in the creation of the ARE.

- The user of the gas installation in \% of the total-the data was considered a stimulant. The high level of gasification indicates that there is potentially little interest among investors in engaging in initiatives to create an ARE. It should also be borne in mind that gas is one of the cheapest energy sources and is environmentally friendly. Therefore, replacing gas with renewable energy sources becomes unattractive.

- $\quad$ Poviatincome per capita-high income allows to start investment activity.

- Average gross monthly salaries-high income allows to start investment activity.

As a result of using Hellwig's method in this study, individual elements of observations (diagnostic variables), which are the characteristics used in the method, have been selected to create a synthetic indicator.

The study continues with standardization variables, using the formula: (variable value-arithmetic mean).

Then, the variable distillates [74] were transformed into stimulants by adopting their inverse. In the study, characteristics were considered to be destimulants: Use of the gas installation in \% of the total. The data thus determined were used to construct the template. The value of the synthetic indicator was determined by the generalised Euclidean distance of the point representing the object from the point of the template. 
The basis for this was the following formula:

$$
\begin{gathered}
C_{i o}=\left[\sum_{k=1}^{k} V_{k}\left(Z_{i k}-Z_{o k}\right)^{2}\right]^{\frac{1}{2}} \\
i=1,2, \ldots n,
\end{gathered}
$$

where:

$C_{i o}$-generalized Euclidean distance of the $i$-th object from the pattern;

$V_{k}$-weight assigned to the $k$-th variable from the set of diagnostic variables;

$Z_{i k}$-standardized $k$-value of this variable for the $i$-th object;

$Z_{o k}$-standardized $k$-value of this variable for the reference object.

However, the measure of development is based on the formula [75]:

$$
H_{i}=1-\frac{C_{i o}}{C_{o}}
$$

where:

$$
\begin{gathered}
C=\overline{C_{o}}+2 S_{o,} \\
\bar{C}_{o}=\frac{1}{n} \sum_{i=1}^{n} C_{i o}, \\
S_{o}=\sqrt{\frac{\sum_{i=1}^{n}\left(C_{i o}-\bar{C}_{o}\right)^{2}}{n-1} .} .
\end{gathered}
$$

where:

$H_{i}$ - the value of a synthetic meter for the $i$-th object;

$C_{i o}$-generalized Euclidean distance of the $i$-th object from the pattern;

$\mathrm{C}_{0}$-a normative factor;

$\mathrm{C}_{0}$-Arithmetic mean of generalized distances of Euclidean objects from the pattern;

$S_{0}$-Standard deviation of the generalized distances of Euclidean objects from the standard.

The weights of the individual factors were determined arbitrarily, as the same values were adopted for all of the examined features [76]. Indicator $H_{i}$ takes values within [0-1]. Its interpretation is as follows: the given poviat is all the more prospective for the creation of the ARE, the closer the value of the measure of development is to unity. Synthetic indicators for districts and diagnostic variables are presented in Table 2.

Table 2. Synthetic indicators.

\begin{tabular}{ccc}
\hline Deposit & County & Hellwig's Index Value \\
\hline 1 & Sochaczew district & 0.2903 \\
2 & Novodvorsk district & 0.2941 \\
3 & Kozienice district & 0.3070 \\
4 & The County of the Pooh & 0.3080 \\
5 & County of Przasnysz & 0.3152 \\
6 & Leipzig County & 0.3161 \\
7 & Maków County & 0.3226 \\
8 & Sokołów County & 0.3265 \\
9 & Zuromin County & 0.3271 \\
10 & Płock County & 0.3280 \\
11 & Ostrołęk County & 0.3298 \\
12 & Zvolen county & 0.3310 \\
\hline
\end{tabular}


Table 2. Cont.

\begin{tabular}{ccc}
\hline Deposit & County & Hellwig's Index Value \\
\hline 13 & Gostynin County & 0.3310 \\
14 & Sierpe County & 0.3318 \\
15 & Ostrów Wielkopolski County & 0.3378 \\
16 & Hungarian County & 0.3458 \\
17 & The district of Salzburg & 0.3482 \\
18 & Szydłowiec County & 0.3533 \\
19 & Pułtusk County & 0.3566 \\
20 & Siedlce County & 0.3660 \\
21 & Plonsk County & 0.3804 \\
22 & Bialobrzeski County & 0.3862 \\
23 & Gyrard County & 0.3875 \\
24 & Radom County & 0.3910 \\
25 & Garwolin district & 0.3930 \\
26 & Ciechanow County & 0.3942 \\
27 & Minsk County & 0.4049 \\
28 & Pruszków County & 0.4225 \\
29 & Grójec County & 0.4232 \\
30 & Otwock County & 0.4313 \\
31 & Wyszków County & 0.4318 \\
32 & Warsaw western poviat & 0.4406 \\
33 & Grodziski County & 0.4417 \\
34 & Mława County & 0.4437 \\
35 & Piaseczno County & 0.4576 \\
36 & Legionowo district & 0.4618 \\
37 & Volomina District & 0.4764 \\
\hline
\end{tabular}

Achieving the goals of the first stage of the study required the adoption of several basic methodological assumptions:

- The number of indicators adopted for the analysis of the synthetic indicator is limited to those that can be obtained from publicly available statistical data of the Central Statistical Office. The analysis included four indicators characterizing various areas of municipal economy functioning, which show a direct or indirect relationship with the ARE potential;

- The analysis was conducted on the basis of statistical data for 2018;

- The study used statistical data from the Central Statistical Office in Warsaw.

The value of the achieved synthetic indicator indicates the difference between the situation of a given municipality and the adopted pattern, which has the best conditions (potential) to create the ARE.

\section{Factors Determining the Introduction of the ARE (Based on Studies)}

Based on the conducted research, the suggestion is to base the ARE on the concept of an open system. The open system is based on the formula of participation in the creation of the region by all stakeholders-both those operating in the ARE area and those not related to the region in any way. In the case of organizing a closed system, only entities located in the ARE may participate in it. In the economy, it is practically impossible for the hermetic, completely closed systems to operate. The technological choice must be specific for each region, based on not only available renewable energy sources, but also taking into account all aspects of the energy, economic, and social transformation processes. The choice of technology should be in line with national and EU regulations and take into account such aspects as energy security, $\mathrm{CO}_{2}$ reduction, and compliance with environmental standards.

At this stage of the ARE construction, particular attention should be paid to public consultation and to examining the acceptance of local communities for the intended purposes. This stage should be preceded by information meetings and advertising, as well as promotion campaigns in a reliable and 
comprehensive manner informing about the advantages and disadvantages, along with opportunities and threats resulting from the undertaken undertakings. It is also crucial to create a platform for the exchange of information enabling the provision of current information on the implementation of the project and the possibility of participation in the project or in its individual stages. Due to the innovativeness of the project, this stage should be spread out in time, and the analysis of social acceptance of the work undertaken should be monitored on an ongoing basis.

\subsection{Recommendations for the Creation of AREs in EU Countries}

Based on the analysis of research results and the literature on the subject, the following principles for the creation of AREs in EU countries are recommended. Local government units fulfilling the tasks provided for by law have a real impact on the social and economic transformations taking place in their territory. They also have a significant effect on spatial development and the state of the natural environment. Therefore, the role of territorial self-governments in the local social space naturally sanctions them to the role of the host of a given area, and the tools at their disposal provide real opportunities to successfully initiate new social and economic initiatives. According to the interviews with local authorities, there is a relatively passive attitude, expressed in anticipation of good practice and fear of political risk. Local governments make their decisions concerning the possible creation of the ARE, as well as the investment decisions in dispersed installations using renewable energy, dependent on obtaining subsidies from external funds.

\subsection{Development of Strategic Energy Policy Documents by Entities Preparing to Co-Create the ARE}

Activities aimed at creating the ARE should be properly prepared and planned. Therefore, strategic and organizational documents that set the "path to energy independence" and the principles of cooperation within the ARE (including the entry and exit of individual stakeholders) play a vital role. In this regard, there are difficulties related to the potential of local government units in terms of the possibility of preparing all legal, organizational and financial aspects of ARE. Due to the degree of difficulty of the project, it is advisable to prepare models of solutions in the discussed scope at the central level. Therefore, a key tool is to create a database of good practices and a platform for the exchange of information, promotion of initiatives taken, and enabling consultation and joint problem solving.

\subsection{Establishing Cooperation with Neighboring Regions}

In economic practice, it is not possible for hermetic, completely closed systems to operate. Taking the initiative to transform the conventional system into a distributed energy system requires a huge effort from the initiators to cover the financial, economic, social, and cultural costs. For regions covering the area of influence of one municipality or even the whole district, these costs may constitute an insurmountable barrier already at the initial stage of the ARE concept. An element of lowering some of the costs is the establishment of cooperation with other regions.

\subsubsection{Acquisition of Knowledge}

As the research has shown, there is a huge information and knowledge barrier (among the representatives of local government) about the possibilities of creating AREs and the opportunities and threats resulting from their creation. Due to the innovativeness of the concept and the dynamics of changes in the renewable energy sector, on the one hand, there is no literature or guides available to address the ARE issues. On the other hand, there is also a lack of ready-made models of individual documents or solutions within the ARE. As a result of this state of affairs, there is a need for individuals aspiring to be energy self-sufficient to make efforts to create individual, original concepts and solutions within the ARE. At present, it unequivocally eliminates from the "game of development" through the use of the ARE passive units, without a specific vision of development or without an appropriate team capable of preparing a concept/strategy for the development of the ARE in their area. 


\subsubsection{Public Confidence Building}

AREs constitute an opportunity to improve not only the quality of life in a given area, but can also be an important instrument for building a positive image of public authority. It should be noted that public security-including energy security-is the domain of the state. Therefore, society has the right to expect permanent access to safe and cheap energy. Both energy prices and disruptions to energy supply have a direct impact on the quality of life and the viability of the business sector.

It should be noted that any changes in prices and disruptions to energy supply have a significant impact on public confidence. The threshold of social acceptability in terms of expenditure on utilities, including mainly energy expenditure is a critical point in this respect. Exceeding the acceptance threshold means that consumers can stop paying for utilities and the whole system of financing them can collapse [77,78].

\subsubsection{Financial Models}

In order to build an ARE, it is necessary to ensure sustainable sources of financing. ARE financing should ensure both the construction of the necessary infrastructure and the operational resources necessary to maintain the financial sustainability of the initiative. The conducted research clearly shows high expectations in relation to all kinds of aid funds. In this context, ARE has a chance to become attractive in terms of other forms of financing, including own funds or dispersed capital, which may come from contributions of individual ARE members.

Crisis areas that can be solved by transforming given regions into ARE include:

- Environmental (related to the transition of economies and society from energy based e.g., on coal and other non-renewable energy sources to RES);

- Health (reducing low emissions affects the quality and health of residents);

- Infrastructural (creating new energy and energy-related infrastructure for the needs of renewable energy sources);

- Labor market (in problem regions, struggling with unemployment problems, renewable energy may be an industry that creates local jobs, including, in particular, an attractive solution for agricultural and post-industrial areas);

- Social (development of local energy infrastructure based on renewable energy sources, where the community is its owner, (co-owner) and manages it, and consequently gains benefits, gives an opportunity to create new social and economic networks, forms local communities focused around common goals);

- Financial (positively affects the wealth of households, entrepreneurs, farmers, or local governments), which, being the owners of the infrastructure, receive direct benefits from it $[78,79]$.

\subsubsection{Links with Other Municipal Services}

Linking with other municipal services should be understood as a comprehensive ARE activity. Municipal companies may be a leader in the ARE construction. As providers of services to the local and regional community, ensuring energy self-sufficiency (or the pursuit of energy self-sufficiency), they have a direct impact on all inhabitants of the region. Savings resulting from the reduction of energy costs can be reinvested in the development of municipal infrastructure or its improvement. Establishing a network of interconnections increases the standard of services offered, and, at the same time, reduces the costs of these services. Municipal enterprises can introduce the "Merit Order" tool for modeling the energy market inside ARE, which is one way of forecasting energy prices depending on production capacity and current energy demand [80,81].

\subsubsection{Creating Energy Clusters and Supporting the Construction of Energy Cooperatives}

A cluster in the general sense of the word is a grouping of specialized entities in a specific area, connected by a network of specific connections, concentrated in a specific industry or related industries, 
which compete with each other and interact with each other. Cluster members are usually entrepreneurs, but their structures include research and scientific units and public authorities. Clusters are created to promote solutions offered by a given industry; they are a forum for the exchange of knowledge, technology, human capital, and technical and research facilities of their members. Their activity is directly related to the policy of developing a sustainable and innovative economy. Therefore, clustering can become an important building block. Energy cooperatives that generate energy for the use of their members are also an indispensable element of each ARE. Due to their local character, apart from building local energy infrastructure, they also create economic and local networks that are important for the functioning of local communities.

\subsubsection{Mobility}

The ARE should, in principle, be aimed at a wide range of activities, including the transport and logistics sectors. Transport is responsible for $5 \%$ of all air pollutants, and in some regions, such as Warsaw, for $60 \%$ of harmful dusts and gases. The already available technologies enable the transition to low-emission or zero-emission rolling stock. The decision on the choice of rolling stock should be dictated by the capabilities of a given region to produce a given type of fuel. As an energy source in the form of biofuel, it is necessary to change the policy of agricultural land use; therefore, the analysis should take into account the impact of this technology on the food industry. Low-emission hydrogen fuel technologies and electromobility have a less negative impact on other sectors of the region's economy.

\section{Advantages and Disadvantages of Introducing ARE}

The advantage is that local government units, when fulfilling the tasks provided for by law, have a real impact on the ongoing socioeconomic changes in their area. Another important aspect significantly influencing the advantage is the information that they also affect spatial development and the condition of the natural environment.

The role of territorial self-governments in the local social space is yet another advantage, it naturally sanctions them to the role of the host of a given area, and the tools at its disposal give real opportunities to successfully initiate new social and economic initiatives.

The fact that ARE is an opportunity to improve not only the quality of life in a given area, but can also be an important instrument for building a positive image of public authority is an indisputable advantage. It should be noted that public safety, including energy security, is the domain of the state. Therefore, society has the right to expect sustainable access to safe and cheap energy. Both energy prices and energy supply disruptions have a direct impact on the quality of life and the viability of the business sector.

Another advantage points to the link with other municipal services in terms of the comprehensive operation of ARE. Municipal companies can be the leader of ARE construction. As entities providing services to the local and regional community, they have a direct impact on all inhabitants of the region by ensuring energy self-sufficiency (or striving for energy self-sufficiency). Savings obtained as a result of reducing energy expenditure may be reinvested in the development of municipal infrastructure or its improvement. The creation of a network of interconnections increases the standard of services offered while reducing the costs of these services.

The advantage of creating clusters should also be indicated, which may become an important element of building ARE. Energy cooperatives, producing energy for the use of cooperative members are also an indispensable element of each ARE. Due to their local nature of activity, in addition to building local energy infrastructure, they also create networks of economic and local connections that are important for the functioning of local communities.

One of the disadvantages of the fact that a relatively passive attitude prevails among local authorities, is expressed in anticipation of good practices and fear of political risk. Local authorities make their decisions regarding the possible creation of ARE, as well as the investment decisions 
themselves in dispersed installations using renewable energy, dependent on obtaining subsidies from external funds.

There are also noticeable difficulties with the potential of local government units with regard to the possibility of preparing all legal, organizational, and financial aspects of ARE.

Another important aspect that requires improvement is the fact that it is not possible for hermetic, completely closed systems to operate in business practice. Taking the initiative to transform a conventional system into a distributed energy system requires from the initiators a huge effort to cover the financial, economic, social, and cultural costs.

Another disadvantage indicates an information barrier about the possibility of creating ARE and the opportunities and threats resulting from their creation. Due to the innovative nature of the concept and the dynamics of changes in the renewable energy sector, on the one hand, there is no available literature or guides dealing with ARE issues. On the other hand, there are also no ready-made templates for individual documents or solutions under ARE. As a result of this state, there is a need for individuals aspiring to be energy self-sufficient to make efforts to create individual, original concepts and solutions within the ARE. This clearly eliminates passive units from the "development game" by using ARE, without a specific vision of development or without an appropriate team capable of preparing the ARE development concept/strategy in their area.

\section{Conclusions}

The EU energy sector is facing many serious challenges. On the one hand, they are related to the global trends of a paradigm shift in the energy sector-the gradual transition from conventional to dispersed (prosumer) energy. The lack of an innovative formal, legal, and organizational structure in the EU public space to solve these problems by preparing and implementing grid solutions in distributed energy, based mainly on local and regional renewable sources and involving local entities from the public, private, and non-profit sectors is also an important issue. ARE is a response to such problems as they will contribute to the creation of organizational and legal tools to counteract the marginalization of crisis areas, where undesirable socioeconomic phenomena are intensifying, and the condition and management of the natural environment is deteriorating. Investments in energy infrastructure based on distributed energy (mainly renewable energy sources) will primarily be a tool for socioeconomic changes in the affected area. Serious problems in many areas, not only in Poland, but throughout the $\mathrm{EU}$, are related, among others, to a high level of unemployment, including a high percentage of those unemployed for a long term and a high percentage of people using various forms of social assistance (benefits, child nutrition), and the use of social assistance is often directly related to the problem of unemployment and poverty. The implementation of the ARE concept, related to investments in renewable energy sources, will significantly affect the solution of the diagnosed problems of social exclusion. ARE will contribute to a significant enhancement of living conditions in a given area and will significantly improve the condition of the natural environment. The research made the verification of the research hypotheses presented in the introduction to the research possible. It is worth emphasizing that the creation of ARE is a modern requirement in connection with global $\mathrm{CO}_{2}$ emissions. Only a sustainable low-carbon economy that can be introduced throughout the European Union through ongoing research is one of the real opportunities for the dynamic development of the entire region.

The lack of proposals for directions of regional development in terms of autonomous energy regions was indicated. There is a need to formulate specific recommendations regarding the possibility of creating autonomous energy regions (AREs) and their effective management in the regions of the European Union. There are natural, organizational, and social opportunities to start the process of creating AREs in EU countries. Local authorities may become local leaders in creating a network of connections in the emerging ARE. It may turn out that local communities make the effort to co-create AREs willingly. 
Author Contributions: Data curation, P.M., G.M.; Formal analysis, H.W.; Funding acquisition, P.M., G.M., H.W., I.M., Ł.K.; Methodology, P.M., G.M.; Project administration, H.W.; Software, P.M., G.M., H.W., I.M. and Ł.K.; Supervision, P.M. and H.W.; Validation, P.M., G.M., H.W., I.M., Ł.K.; Visualization, P.M., G.M. and H.W.; Writing-original draft, G.M., P.M. and H.W.; Writing—review \& editing, H.W. and I.M. All authors have read and agreed to the published version of the manuscript.

Funding: This research received no external funding.

Conflicts of Interest: The authors declare no conflict of interest.

\section{References}

1. Reiss, P.C.; White, M.W. Household electricity demand, revisited. Rev. Econ. Stud. 2005, 72, 853-883. [CrossRef]

2. Bruckmeier, K. LEADER in Germany and the discourse of autonomous regional development. Sociol. Rural. 2000, 40, 219-227. [CrossRef]

3. Späth, P.; Rohracher, H. 'Energy regions': The transformative power of regional discourses on socio-technical futures. Res. Policy 2010, 39, 449-458. [CrossRef]

4. Armstrong, H.; Read, R. Western European micro-states and EU autonomous regions: The advantages of size and sovereignty. World Dev. 1995, 23, 1229-1245. [CrossRef]

5. Aschauer, D.A. Is public expenditure productive? J. Monet. Econ. 1989, 23, 177-200. [CrossRef]

6. Amacher, G.S.; Hyde, W.F.; Kanel, K.R. Nepali fuelwood production and consumption: Regional and household distinctions, substitution and successful intervention. J. Dev. Stud. 1999, 35, 138-163. [CrossRef]

7. Albi, A. EU Enlargement and the Constitutions of Central and Eastern Europe; Cambridge University Press: Cambridge, UK, 2005.

8. Kok, R.; Benders, R.M.; Moll, H.C. Measuring the environmental load of household consumption using some methods based on input-output energy analysis: A comparison of methods and a discussion of results. Energy Policy 2006, 34, 2744-2761. [CrossRef]

9. Ghisi, E.; Tinker, J.A. An ideal window area concept for energy efficient integration of daylight and artificial light in buildings. Build. Environ. 2005, 40,51-61. [CrossRef]

10. Brown, H.S.; Vergragt, P.J. Bounded socio-technical experiments as agents of systemic change: The case of a zero-energy residential building. Technol. Forecast. Soc. Chang. 2008, 75, 107-130. [CrossRef]

11. Gann, D.M.; Salter, A.J. Innovation in project-based, service-enhanced firms: The construction of complex products and systems. Res. Policy 2000, 29, 955-972. [CrossRef]

12. Lechtenböhmer, S.; Schüring, A. The potential for large-scale savings from insulating residential buildings in the EU. Energy Effic. 2011, 4, 257-270. [CrossRef]

13. Lewis, D. Energy positive: How Denmark's Samso Island switched to zero carbon. Habitat Aust. 2017, 45, 14.

14. Watson, I.; Betts, S.; Rapaport, E. Determining appropriate wind turbine setback distances: Perspectives from municipal planners in the Canadian provinces of Nova Scotia, Ontario, and Quebec. Energy Policy 2012, 41, 782-789. [CrossRef]

15. Bazan-Krzywoszańska, A.; Mrówczyńska, M.; Skiba, M.; Łączak, A. Economic conditions for the development of energy efficient civil engineering using RES in the policy of cohesion of the European Union (2014-2020). Case study: The town of Zielona Gora. Energy Build. 2016, 118, 170-180. [CrossRef]

16. EC-European Commission. Directive 2010/75/EU of the European Parliament and of the Council of 24 November 2010 on industrial emissions (integrated pollution prevention and control). Off. J. Eur. Union 2010, L334, 17-119.

17. EC-European Commission. Directive 2009/72/EC of the European Parliament and of the Council of 13 July 2009 concerning common rules for the internal market in electricity and repealing Directive 2003/54/EC. Off. J. Eur. Union 2009, L112, 55-93. Available online: https://eur-lex.europa.eu/LexUriServ/LexUriServ.do?uri=OJ: L:2009:211:0055:0093:EN:PDF (accessed on 22 January 2020).

18. A Policy Framework for Climate and Energy in the Period from 2020 to 2030. A Strategy for Competitive, Sustainable and Secure Energy. Available online: http://eur-lex.europa (accessed on 12 January 2020).

19. EC-European Commission. Directive 2009/28/EC on Renewable Energy (Promoting Technologies such as Electric Car, Heat Pump, Second-Generation Fuels); EC-European Commission: Brussels, Belgium, 2009. 
20. Directive 2010/31/EC (Creating Sustainable Construction, Including a Zero-Energy House). Available online: https://eur-lex.europa.eu/LexUriServ/LexUriServ.do?uri=OJ:L:2010:153:0013:0035:en:PDF (accessed on 24 January 2020).

21. Scarlat, N.; Dallemand, J.F.; Monforti-Ferrario, F.; Banja, M.; Motola, V. Renewable energy policy framework and bioenergy contribution in the European Union-An overview from National Renewable energy action plans and progress reports. Renew. Sustain. Energy Rev. 2015, 51, 969-985. [CrossRef]

22. Van Leeuwen, M.G.; Vermeulen, W.J.; Glasbergen, P. Planning eco-industrial parks: An analysis of Dutch planning methods. Bus. Strategy Environ. 2003, 12, 147-162. [CrossRef]

23. European Commission. Analysis Associated with the Roadmap to a Resource Efficient Europe. Available online: http://ec.europa.eu/environment/resource_efficiency/pdf/working_paper_part1.pdf (accessed on 20 May 2020).

24. Miciuła, I.; Stępień, P. The impact of current EU climate and energy policies on the economy of Poland. Pol. J. Environ. Stud. 2019, 28, 2273-2280. [CrossRef]

25. Vavrek, R.; Chovancova, J. Assessment of economic and environmental energy performance of EU countries using CV-TOPSIS technique. Ecol. Indic. 2019, 106, 105519. [CrossRef]

26. Hou, P.; Enevoldsen, P.; Eichman, J.; Hu, W.; Jacobson, M.Z.; Chen, Z. Optimizing investments in coupled offshore wind-electrolytic hydrogen storage systems in Denmark. J. Power Sources 2017, 359, 186-197. [CrossRef]

27. Jansen, M.; Staffell, I.; Kitzing, L.; Quoilin, S.; Wiggelinkhuizen, E.; Bulder, B.; Riepin, I.; Müsgens, F. Offshore wind competitiveness in mature markets without subsidy. Nat. Energy 2020, 5, 614-622. [CrossRef]

28. Kandil, M.S.; Farghal, S.A.; El-Alfy, A.E. Optimum operation of an autonomous energy system suitable for new communities in developing countries. Electr. Power Syst. Res. 1991, 21, 137-146. [CrossRef]

29. Toke, D. The UK offshore wind power programme: A sea-change in UK energy policy? Energy Policy 2011, 39, 526-534. [CrossRef]

30. Pulselli, R.M.; Simoncini, E.; Marchettini, N. Energy and emergy based cost-benefit evaluation of building envelopes relative to geographical location and climate. Build. Environ. 2009, 44, 920-928. [CrossRef]

31. Carvalho, M.; Serra, L.M.; Lozano, M.A. Geographic evaluation of trigeneration systems in the tertiary sector. Effect of climatic and electricity supply conditions. Energy 2011, 36, 1931-1939. [CrossRef]

32. Lund, H. Renewable energy strategies for sustainable development. Energy 2007, 32, 912-919. [CrossRef]

33. Miciuła, I.; Wojtaszek, H.; Bazan, M.; Janiczek, T.; Włodarczyk, B.; Kabus, J.; Kana, R. Management of the energy mix and emissivity of individual economies in the european union as a challenge of the modern world climate. Energies 2020, 13, 5191. [CrossRef]

34. Hongrapipat, J.; Siriwongrungson, V.; Messner, M.; Henrich, C.; Gunnarsson, S.; Koch, M.; Hofbauer, H. Co-gasification of cassava rhizome and woody biomass in the $1 \mathrm{MWel}$ prototype dual fluidized bed gasifier by gussing renewable energy. In Proceedings of the IOP Conference Series: Earth and Environmental Science, Sanya, China, 12-15 March 2020; IOP Publishing: Bristol, UK, 2020; Volume 495, No. 1. p. 012019.

35. Barragan-Escandon, A.; Terrados-Cepeda, J.; Zalamea-Leon, E.; Arias-Reyes, P. Electricity production using renewable resources in urban centres. Proc. Inst. Civ. Eng. Energy 2018, 171, 12-25. [CrossRef]

36. Kanellakis, M.; Martinopoulos, G.; Zachariadis, T. European energy policy-A review. Energy Policy 2013, 62, 1020. [CrossRef]

37. Goodstein, D.; Intriligator, M. Climate Change and the Energy Problem: Physical Science and Economics Perspective; World Scientific Publishing Co Pte Ltd.: Singapore, 2013.

38. Banos, R.; Manzano-Agugliaro, F.; Montoya, F.G.; Gil, C.; Alcayde, A.; Gómez, J. Optimization methods applied to renewable and sustainable energy: A review. Renew. Sustain. Energy Rev. 2011, 15, 1753-1766. [CrossRef]

39. Szulecki, K.; Fischer, S.; Gullberg, A.T.; Sartor, O. Shaping the Energy Union': Between national positions and governance innovation in EU energy and climate policy. Clim. Policy 2016, 16, 548. [CrossRef]

40. Kern, S.; Pfeifer, C.; Hofbauer, H. Synergetic utilization of renewable and fossil fuels: Dual fluidized bed steam co-gasification of coal and wood. APCBEE Procedia 2012, 1, 136-140. [CrossRef]

41. Marcelja, D. Self-sufficient community: Vision or reality? Creating a regional renewable energy supply network (Güssing, Austria). Local Gov. Clim. Chang. 2010, 217-228. [CrossRef] 
42. Menges, G.; Sherif, S.A. International comparison of industrial production structures: Application of a taxonomic method to the input-output tables of the economic commission for Europe. Stat. Hefte 1977, 18, 83-122. [CrossRef]

43. Clarke, M.; Wilson, A.G. The dynamics of urban spatial structure: The progress of a research programme. Trans. Inst. Br. Geogr. 1985, 427-451. [CrossRef]

44. International Atomic Energy Agency. Available online: http://www.iaea.org (accessed on 23 December 2018).

45. Agency. Available online: www.reo.pl (accessed on 2 December 2018).

46. World Nuclear Association. Available online: http://www.world-nuclear.org/ (accessed on 15 December 2019).

47. Herrmann, C.; Thiede, S. Process chain simulation to foster energy efficiency in manufacturing. CIRP J. Manuf. Sci. Technol. 2009, 1, 221-229. [CrossRef]

48. Barragán-Escandón, A.; Terrados-Cepeda, J.; Zalamea-León, E. The role of renewable energy in the promotion of circular urban metabolism. Sustainability 2017, 9, 2341. [CrossRef]

49. Helm, D. The European framework for energy and climate policies. Energy Policy 2014, 64, 29-35. [CrossRef]

50. Miciuła, I.; Stępień, P. Analysis of the Global market of energy resources. Eurasian Bus. Perspect. 2019, 10, 85-96.

51. Clean Energy Australia Report. Available online: https://www.cleanenergycouncil.org.au/policy-advocacy/ reports/clean-energy-australia-report.html (accessed on 9 June 2017).

52. Thakur, J.; Chakraborty, B. Demand side management in developing nations: A mitigating tool for energy imbalance and peak load management. Energy 2016, 114, 895-912. [CrossRef]

53. Szulecki, K.; Fischer, S.; Gullberg, A.T.; Sartor, O. Giving shape to the Energy Union: Evolution, national expectations and implications for EU energy and climate governance. SSRN Electron. J. 2015. [CrossRef]

54. Mitraka, Z.; Chrysoulakis, N.; Kamarianakis, Y.; Partsinevelos, P.; Tsouchlaraki, A. Improving the estimation of urban surface emissivity based on sub-pixel classification of high resolution satellite imagery. Remote Sens. Environ. 2012, 117, 125-134. [CrossRef]

55. Huo, T.; Ren, H.; Zhang, X.; Cai, W.; Feng, W.; Zhou, N.; Wang, X. China's energy consumption in the building sector: A statistical yearbook-energy balance sheet based splitting method. J. Clean. Prod. 2018, 185, 665-679. [CrossRef]

56. Nazara, S.; Hewings, G.J. Spatial structure and taxonomy of decomposition in shift-share analysis. Growth Chang. 2004, 35, 476-490. [CrossRef]

57. Apps, P.F.; Rees, R. Collective labor supply and household production. J. Political Econ. 1997, 105, 178-190. [CrossRef]

58. Mantzos, L.; Capros, P.; Kouvaritakis, N.; Zeka-Paschou, M.; Chesshire, J.; Guilmot, J.F. European Energy and Transport Trends to 2030; Office for Official Publications of the European Communities: Luxembourg, 2003.

59. Franco, A.; Diaz, A.R. The future challenges for "clean coal technologies": Joining efficiency increase and pollutant emission control. Energy 2009, 34, 348-354. [CrossRef]

60. Schubert, S.R.; Pollak, J.; Kreutler, M. Energy Policy of the European Union; Macmillan International Higher Education: London, UK, 2016.

61. Andanova, L.B. The Europeanization of Environmental Policy in Central and Eastern Europe. In The Europeanization of Central and Eastern Europe; Schimmelfennig, F., Sedelmeier, U., Eds.; Cornell Studies in Political Economy: New York, NY, USA, 2005; pp. 135-155. Available online: https://www.ihs.ac.at/ publications/lib/fo1.pdf (accessed on 15 January 2019).

62. Mišík, M.; Nosko, A. The Eastring gas pipeline in the context of the Central and Eastern European gas supply challenge. Nat. Energy 2017, 2, 844-848. [CrossRef]

63. Eurostat Data. Available online: http://ec.europa.eu/eurostat (accessed on 31 December 2019).

64. Góralczyk, M. Life-cycle assessment in the renewable energy sector. Appl. Energy 2003, 75, $205-211$. [CrossRef]

65. Chastas, P.; Theodosiou, T.; Bikas, D. Embodied energy in residential buildings-towards the nearly zero energy building: A literature review. Build. Environ. 2016, 105, 267-282. [CrossRef]

66. Shah, S.A.A.; Zhou, P.; Walasai, G.D.; Mohsin, M. Energy security and environmental sustainability index of South Asian countries: A composite index approach. Ecol. Indic. 2019, 106, 105507. [CrossRef]

67. Švedas, R. EU energy Island-characteristics, threats, and how to break out of it: A case study of Lithuania. Lith. Annu. Strateg. Rev. 2017, 15, 179-209. [CrossRef] 
68. Falkner, R. The political economy of 'normative power' Europe: EU environmental leadership in international biotechnology regulation. J. Eur. Public Policy 2007, 14, 507-526. [CrossRef]

69. Maltby, T. European union energy policy integration: A case of European Commission policy entrepreneurship and increasing supranationalism. Energy Policy 2013, 55, 435-444. [CrossRef]

70. Langsdorf, S. EU Energy Policy: From the ECSC to the Energy Roadmap 2050; Green European Foundation: Brussels, Belgium, 2011.

71. Tian, H.; Wang, Y.; Xue, Z.; Qu, Y.; Chai, F.; Hao, J. Atmospheric emissions estimation of Hg, As, and Se from coal-fired power plants in China, 2007. Sci. Total Environ. 2011, 409, 3078-3081. [CrossRef]

72. Saikia, J.; Roy, S.; Bordoloi, M.; Saikia, P.; Saikia, B.K. Atmospheric aerosols around three different types of coal-based industries: Emission parameters, cytotoxicity assay, and principal component analysis. J. Aerosol Sci. 2018, 126, 21-32. [CrossRef]

73. Zhang, J.; Ning, Y.; Liu, C.; Li, Z.; Wang, H.; Chen, L.; Lu, C. Monitoring and analysis of effect of project" replacing coal with electricity" improving atmospheric environmental quality in Mentougou District, Beijing. J. Ecol. Rural Environ. 2017, 33, 898-906.

74. Gibbs, D.; Deutz, P.; Proctor, A. Industrial ecology and eco-industrial development: A potential paradigm for local and regional development? Reg. Stud. 2005, 39, 171-183. [CrossRef]

75. Renewable Energy and Jobs: Annual Review; IRENA (International Renewable Energy Agency): Abu Dhabi, UAE, 2016.

76. Borovits, I.; Carol, A. International comparison of industrial structures using input-Output analysis. Long Range Plan. 1973, 6, 63-68. [CrossRef]

77. Wilson, A.G.; Birkin, M. Dynamic models of agricultural location in a spatial interaction framework. Geogr. Anal. 1987, 19, 31-56. [CrossRef]

78. Mayor, M.; López, A.J. Spatial shift-share analysis versus spatial filtering: An application to Spanish employment data. In Spatial Econometrics; Physica-Verlag HD: Heidelberg, Germany, 2008; pp. 123-142. [CrossRef]

79. Quarantelli, E.L. Disaster crisis management: A summary of research findings. J. Manag. Stud. 1988, 25, 373-385. [CrossRef]

80. Chiappori, P.A. Introducing household production in collective models of labor supply. J. Political Econ. 1997, 105, 191-209. [CrossRef]

81. Herrmann, C.; Thiede, S.; Kara, S.; Hesselbach, J. Energy oriented simulation of manufacturing systems-Concept and application. CIRP Ann. 2011, 60, 45-48. [CrossRef]

Publisher's Note: MDPI stays neutral with regard to jurisdictional claims in published maps and institutional affiliations.

(C) 2020 by the authors. Licensee MDPI, Basel, Switzerland. This article is an open access article distributed under the terms and conditions of the Creative Commons Attribution (CC BY) license (http://creativecommons.org/licenses/by/4.0/). 